University of Nebraska - Lincoln

DigitalCommons@University of Nebraska - Lincoln

$6-2012$

\title{
An Assessment of Re-Directing Breeding Waterfowl Conservation Relative to Predictions of Climate Change
}

Charles R. Loesch

Ronald E. Reynolds

LeRoy T. Hansen

Follow this and additional works at: https://digitalcommons.unl.edu/usfwspubs

This Article is brought to you for free and open access by the US Fish \& Wildlife Service at

DigitalCommons@University of Nebraska - Lincoln. It has been accepted for inclusion in US Fish \& Wildlife Publications by an authorized administrator of DigitalCommons@University of Nebraska - Lincoln. 


\title{
Articles
}

\section{An Assessment of Re-Directing Breeding Waterfowl Conservation Relative to Predictions of Climate Change}

\author{
Charles R. Loesch,* Ronald E. Reynolds, LeRoy T. Hansen \\ C.R. Loesch, R.E. Reynolds \\ U.S. Fish and Wildlife Service, Region 6, Habitat and Population Evaluation Team, 3425 Miriam Avenue, Bismarck, North \\ Dakota 58501
}

Current address of R.E. Reynolds, retired: 5817 Dale Avenue, Edina, Minnesota 55436

\section{L.T. Hansen}

U.S. Department of Agriculture, Economic Research Service, 355 E Street NW, Suite 16, Washington, D.C. 20024

\begin{abstract}
The U.S. Fish and Wildlife Service has a long history of habitat conservation in the Prairie Pothole Region (PPR) of the United States that has focused on migratory birds, particularly waterfowl. The ongoing acquisition program of the U.S. Fish and Wildlife Service National Wildlife Refuge System has conserved approximately 1.1 million hectares of critical breeding waterfowl habitat. Results of recent predicted future climate scenarios are being used to suggest that waterfowl conservation be shifted away from currently important areas in the western and central portions of the U.S. PPR eastward, to locations where wetland and climate models suggest may become more conducive for providing wetland habitat for breeding ducks in the future. We used 24 years of breeding waterfowl and wetland monitoring data collected by the U.S. Fish and Wildlife Service National Wildlife Refuge System in the PPR of North and South Dakota and northeast Montana, along with land value and restoration cost data to conduct an economic assessment of the biological risk of refocusing waterfowl conservation efforts eastward due to recent projections of climate change. We considered the immediate risk of the loss of existing wetland and grassland resources in the western portion of the U.S. PPR, their current carrying capacity and production potential, the financial cost of protection vs. restoration relative to current conservation priorities, and the uncertainty of climate change effects on waterfowl habitat distribution. Because unprotected wetland and grassland habitats exist in the western and central portions of the PPR that are important for maintaining current waterfowl carrying capacity and productivity, and climate change effects are highly uncertain, maintaining the current focus of habitat protection appears to be the most cost effective approach for waterfowl habitat conservation efforts. Additionally, continued intensive monitoring activities designed to detect changing waterfowl populations and upland and wetland habitat as they relate to anthropogenic impacts (e.g., pattern tile drainage, grassland conversion) and climatic changes (e.g., wetland hydro-period), should provide more precise results to inform and adapt management and conservation activities accordingly should spatial and temporal changes in wet-dry cycles occur in the future.
\end{abstract}

Keywords: Prairie Pothole Region; economic assessment; waterfowl; climate change; breeding pairs; hatchlings

Received: March 16, 2011; Accepted: November 15, 2011; Published Online Early: December 2011 ; Published: June 2012

Citation: Loesch CR, Reynolds RE, Hansen LT. 2012. An assessment of re-directing breeding waterfowl conservation relative to predictions of climate change. Journal of Fish and Wildlife Management 3(1):1-22; e1944-687X. doi: 10.3996/ 032011-JFWM-020

Copyright: All material appearing in the Journal of Fish and Wildlife Management is in the public domain and may be reproduced or copied without permission unless specifically noted with the copyright symbol (C). Citation of the source, as given above, is requested.

The findings and conclusions in this article are those of the author(s) and do not necessarily represent the views of the U.S. Fish and Wildlife Service.

* Corresponding author: chuck_loesch@fws.gov 


\section{Introduction}

The Prairie Pothole Region (PPR) is recognized as one of the most productive areas for waterfowl in North America (Bellrose 1980, Batt et al. 1989). Of particular importance in recent years is the portion of the U.S. PPR occurring in North Dakota, South Dakota and northeast Montana (hereafter the region). During the period 19922009 about 20\% of the breeding duck population recorded in the U.S. Fish and Wildlife Service (FWS)/ Canadian Wildlife Service traditional May waterfowl survey occurred in the region though it makes up only about $7 \%$ of the total area surveyed (U.S. Fish and Wildlife Service 1992-2009 [FWS 2010a]). Because of the region's importance to nesting waterfowl, the FWS National Wildlife Refuge System (NWRS) has invested heavily in habitat protection and restoration in the region for over 50 years. In 1958, the U.S. Congress amended the Migratory Bird Hunting Stamp Act (commonly referred to as "Duck Stamp Act") of 1934 (16 U.S.C. 718-718j, 48 Stat.452) that authorized the FWS to purchase waterfowl production areas in fee title (meaning the FWS owns and manages the land) or with limited-interest easements through the Small Wetlands Acquisition Program (P.L. 85-585; 72 Stat. 486). Since 1958 , the source of funding for this conservation has mainly been derived from the Migratory Bird Conservation Fund generated from the sale of Duck Stamps, as well as the North American Wetlands Conservation Act fund (FWS 2010b) with matching contributions from non-federal partners participating in the North American Waterfowl Management Plan.

In the early years of the Small Wetlands Acquisition Program, habitat to be conserved was identified by FWS biologists who used their knowledge of the area to prioritize acquisitions. Since 1993, spatially explicit habitat and biological data and predictive statistical models have been developed (Reynolds et al. 1996) and used by the FWS and its conservation partners to prioritize the delivery of conservation activities within the U.S. PPR. The results have focused habitat acquisition and restoration efforts toward areas that produce the greatest migratory bird benefits for limited conservation funds (Reynolds et al. 2006; Niemuth et al. 2008).

Current habitat conservation activities in the region are comprised primarily of limited-interest easements where land-use rights are purchased from willing landowners (e.g., wetland drainage, grassland conversion). Ownership remains with the seller and resources (e.g., wetland, grassland) are protected into perpetuity. To date, the FWS acquisition program has protected approximately 0.22 million hectares of wetland habitat and 0.34 million hectares of grassland habitat through perpetual, limited-interest easements (FWS 2011). The FWS Habitat and Population Evaluation Team, Bismarck, North Dakota (HAPET), has identified an additional 0.64 million wetland hectares and 3.84 million grassland hectares that require protection to secure the current waterfowl productivity potential of the region as it relates to breeding pair habitat and upland nesting cover. In addition to use by the FWS, these data and model outputs are also used by other federal agencies to target conservation actions such as the U.S. Department of Agriculture's (USDA) Conservation Reserve Program (CRP) (e.g., CP-37 known as "Duck Nesting Habitat Initiative"). Most of the conservation practices by USDA initiatives have been designed, at least partially, to offset the loss of wetland and upland habitat resulting from conversion of habitat for crop production. Through these programs, habitat restoration efforts for waterfowl have focused on landscapes where some threshold of other important habitat (e.g., wetland and grassland) remains that attracts and supports moderate to high breeding populations of waterfowl.

A major assumption inherent to the current conservation approach is that past distributions of waterfowl habitat and populations are relatively representative of future distributions. Potential redistribution of breeding waterfowl populations due to habitat changes (i.e., loss) from agriculture activity are considered, but impacts from other changes such as climate change have not been considered in conservation prioritization primarily because of the uncertainty of forecasting such change (Nichols et al. 2011). Indeed, the current conservation approach is designed to reduce habitat losses from conversion to other uses. However, climate change may have an impact on the future size and distribution of duck populations due to changes in habitat quality, availability, and distribution (Bethke and Nudds 1995; Sorenson et al. 1998; Anderson and Sorenson 2001; Johnson et al. 2010).

Simulations for climate change scenarios suggest that changes may occur in future wetland hydrology and that a warmer, drier climate would subsequently shift the distribution of waterfowl within the PPR in response to shifting wetland resources (Bethke and Nudds 1995; Johnson et al. 2005, 2010). Some simulations also suggest the most productive habitat for breeding waterfowl would shift under a predicted drier climate from the PPR of North and South Dakota and southeastern Saskatchewan to areas of the eastern and northern fringes of the PPR (Johnson et al. 2005). Results from simulations that specifically addressed wetland hydroperiod suggest that wetlands in the PPR (Larson 1995; Sorenson et al. 1998; Johnson et al. 2010), especially seasonal wetlands (Johnson et al. 2010), are extremely sensitive to climate warming and that a large portion of the PPR may be too dry to support historic levels of breeding waterfowl. Johnson et al. (2005, 2010) interpreted their results to suggest that climate change may diminish the benefits of wetland conservation in the central and western PPR and that unless wetlands along the eastern and northern fringes are protected and restored, there is little insurance for waterfowl against future climate warming. They further stated that their "findings appear solid enough to serve as the foundation from which to develop management plans to prepare for and adapt to climate change in the PPR".

Based on these conclusions, some wildlife managers promote shifting focus from the current most productive areas of the PPR, to areas farther east where limited nesting and breeding habitat remains and extensive 
restoration of habitat is required. Others suggest that it would take extreme differential changes in climate to render the habitat in the western areas of the U.S PPR less productive than the far eastern areas where we have witnessed extensive wetland and grassland habitat loss due to conversion for other uses (Dahl 1990; FWS HAPET, Bismarck, North Dakota, unpublished data). We examine the potential economic and biological cost of shifting conservation focus away from protecting the current productive habitats of the western portion of the PPR, toward the eastern portion of the region where most wetland and upland habitat has been converted to crop agriculture and extensive restoration is required.

\section{Methods}

\section{Distribution and productivity of waterfowl in North and South Dakota and northeast Montana}

We used data collected from an operational breeding waterfowl population and habitat survey (i.e., 4-mi ${ }^{2}$ sample design [FSM]) to estimate the number and distribution of breeding pairs in North and South Dakota, and northeast Montana. The FSM was developed for the FWS NWRS by the U.S. Geological Survey, Northern Prairie Wildlife Research Center, Jamestown, North Dakota (Cowardin et al. 1995), and was designed to annually collect information to assess the impact of landscape level changes in habitat (e.g., conservation actions, habitat conversion, and natural perturbations) on breeding waterfowl populations. Coordinated by HAPET, the FSM consists of monitoring breeding waterfowl populations, wetland surface hydrology (i.e., wet area) of $\sim 50,000$ wetlands, and land-use of nearly 0.41 million hectares of surrounding upland habitat on $335-3803.22 \mathrm{~km} \times$ $3.22 \mathrm{~km}$ sample plots distributed across the region. Data from this survey were used to describe the size and distribution of breeding waterfowl populations from 1987-2008 and relate populations with upland and wetland habitats to create decision support tools for targeting wetland and grassland conservation treatments (see Reynolds et al. 2006; Niemuth et al. 2008). This decision support system targets habitat conservation using historic relationships between species and habitat characteristics. Appropriateness of this system for management in the future is predicated on those relationships remaining consistent through time.

Basin wetness. The distribution, amount, and timing of precipitation vary annually across the region. As a result, the amount and distribution of surface water in wetland basins during the waterfowl breeding season are highly variable. We used high-resolution aerial imagery collected annually during from 1987-2008 to monitor the condition or wetness of all wetland basins on the FSM survey blocks during May, and digitally mapped $\geq 1$ million wetland-years. Surface water was manually interpreted and digitally mapped from annual imagery for each sample basin and the results were used to develop wetland behavior models (Reynolds et al. 2006). We applied these wetness models to all 2.6 million wetland basins (Figure 1) in the region to predict the average basin wet area (i.e., percent full). We used wetlands mapped by FWS National Wetland Inventory (Cowardin et al. 1979) to classify each basin into one of four wetland basin classes (i.e., temporary, seasonal, semi-permanent, lake) and one class called river (Cowardin et al. 1995; Johnson and Higgins 1997). The predicted average percent fullness of basins was a function of class, size, location, and proximity to sampled wetlands (Reynolds et al. 2006).

Waterfowl breeding pairs. During 1987-2008, field crews recorded over 500,000 observations of breeding waterfowl pairs associated with specific wetlands of measured size, class, location, and basin wet area. We used data from this survey to develop breeding pairwetland relationship models (Reynolds et al. 2006). We used the wetness models to estimate the average percent full during May when ducks settle on the breeding grounds for each of the 2.6 million wetland basins, and then used the pair-wetland relationship models to estimate the carrying capacity for each of the wetlands in the region for five species of upland nesting ducks (i.e., blue-winged teal [Anas discors], gadwall [A. strepera], mallard [A. platyrhynchos], northern pintail [A. acuta], northern shoveler [A. clypeata]) and summarized estimated pairs for each $2.59 \mathrm{~km}^{2}$ section in the region (Table S1, Table S2, Supplemental Material, http://dx.doi. org/10.3996/032011-JFWM-020.S1). Three iterations of the predictive pair models have been developed over the 24 years of the FSM survey as additional data have been collected; the most recent was in 2008.

Waterfowl productivity. The five species of ducks in this assessment nest predominantly in upland habitats. Hoekman et al. (2002) found that nest success is a primary driver of population maintenance and growth for mallards, and nest success is positively related to the percent of grasslands in landscapes (Reynolds et al. 2001; Stephens et al. 2005). We used the relationship from Reynolds et al. (2001) to model the relative productivity of ducks in areas with different mixes of wetland and grassland composition. Our measure of production was the conceptual modelbased prediction of duck eggs hatched (hereafter hatchlings). Hatchlings for a specific location were predicted to be a function of breeding duck population size, nest success, clutch size, and re-nesting propensity (Hansen et al. in prep). We calculated weighted averages for the intercept in the nest daily survival rate model (Reynolds et al. 2001), used exposure days to convert daily survival rate to nest success, and predicted clutch size using the local population composition estimated from waterfowl breeding pair models. For the number of nests per breeding female we used a constant (i.e., 1.72) derived from re-nesting propensity for the five species (Bellrose 1980) (Table S1, Table S2, Supplemental Material, http://dx. doi.org/10.3996/032011-JFWM-020.S1). For the economic assessment, hatchlings per unit-of-area were converted to hatchlings per unit-of-cost (see conservation treatments section below) separately for conservation easements and habitat restoration (Table S3, Supplemental Material, http:// dx.doi.org/10.3996/032011-JFWM-020.S1).

Effect of the spatial distribution of wetland percent full and carrying capacity of breeding waterfowl pairs. To demonstrate the effect of geographic location on wetland 


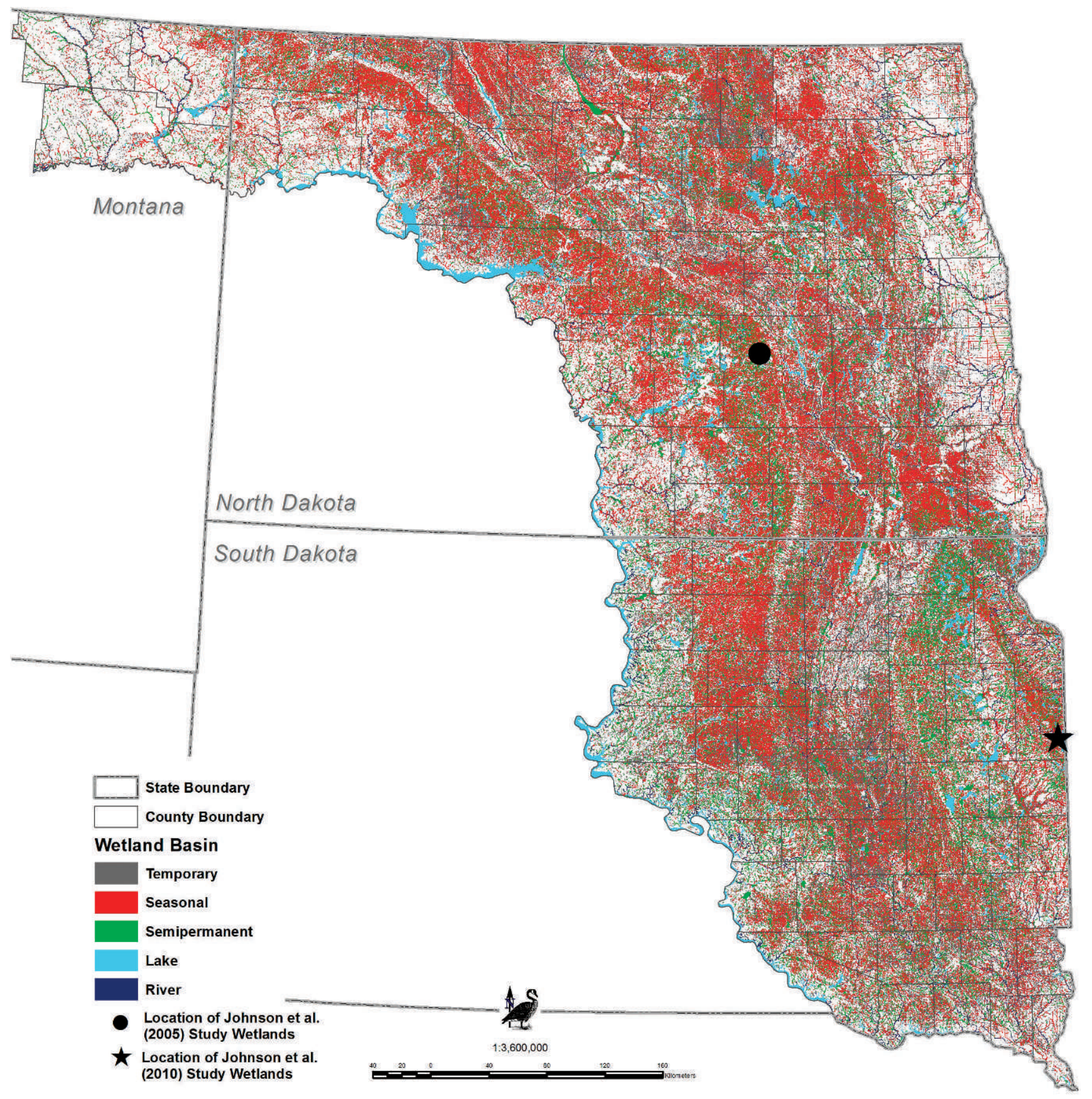

Figure 1. Distribution of wetland basins and rivers in the Prairie Pothole Region of North and South Dakota, and northeastern Montana derived from U.S. Fish and Wildlife Service, National Wetlands Inventory photography collected during 1979-1984. Eighty percent of the wetlands in the area are small ( $<0.41 \mathrm{ha}$ ); consequently, the area of individual basins was exaggerated to visually illustrate the density and distribution of the four classes of wetland basins and rivers.

behavior and pair attractiveness, we used wetland-percentfull and pair-wetland relationship models (Reynolds et al. 2006) and modeled two scenarios of wetland-location interactions. In the first scenario we simulated the effect of location on average percent full for individual wetlands by holding basin size (i.e., $0.61 \mathrm{ha}$ ) and class (i.e., seasonal) constant across the landscape and modeling percent full for $5 \mathrm{~km}^{2}$ units for the region (Table S4, Supplemental Material, http://dx.doi.org/10. 3996/032011-JFWM-020.S1; Figure 2). To demonstrate the effect of wetland location on breeding duck pair density, we used our models to simulate the distribution of duck pairs if wetlands were distributed equally across the region and percent full was constant for each $2.59 \mathrm{~km}^{2}$ section of the region (Figure 3). For this exercise we used a 0.89 ha seasonal wetland (i.e., average size of restored seasonal wetland in North Dakota and South Dakota by the FWS Partners for Fish and Wildlife Program). The results are the expected distribution of percent full (Figure 2) and duck pairs 


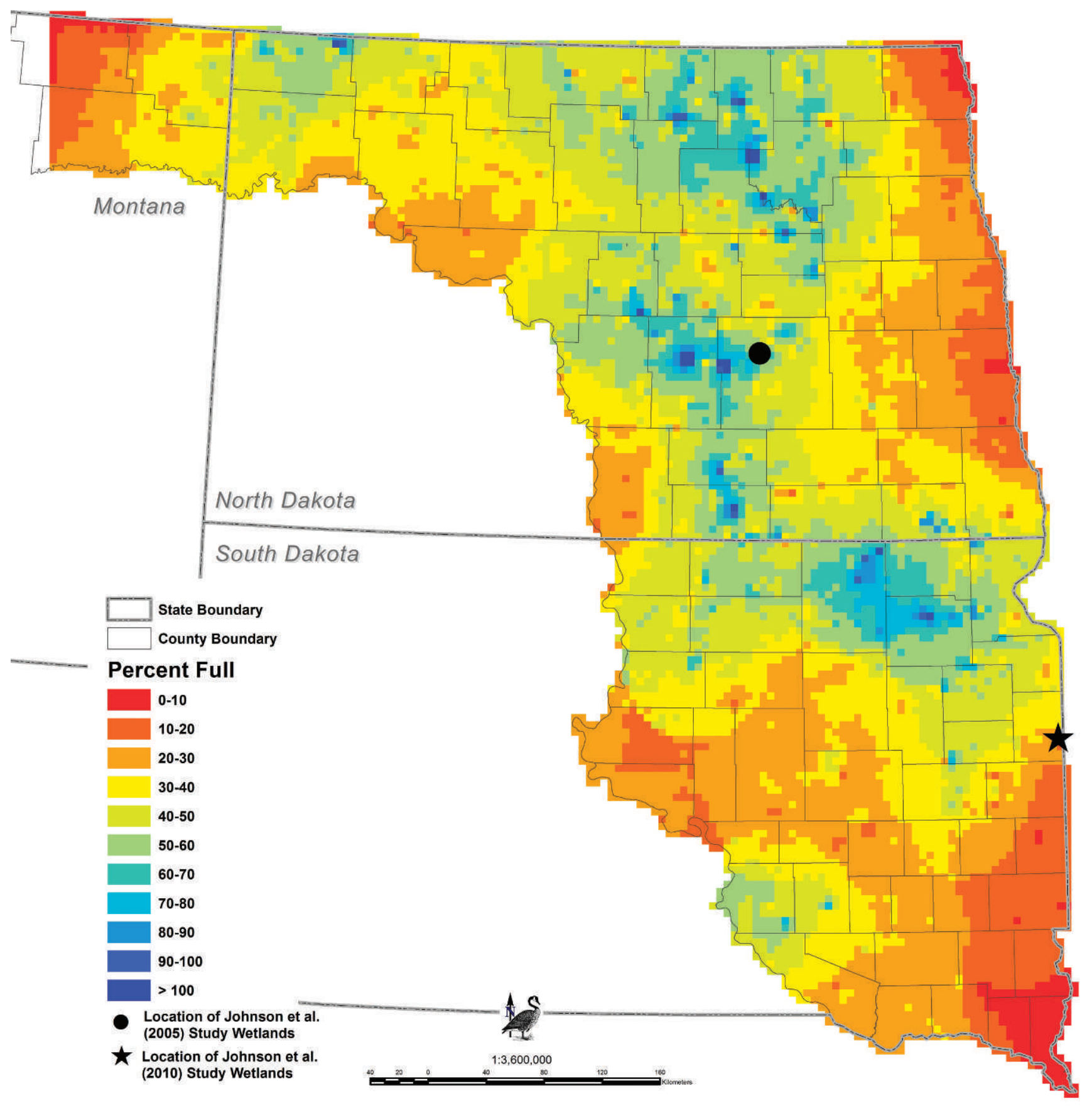

Figure 2. Estimated average percent of a 0.61 ha seasonal wetland basin surface area inundated by water (i.e., percent full) in May during the period 1987-2008 under a scenario where one 0.61 ha seasonal wetland is distributed uniformly (i.e., 1 wetland / $2.59 \mathrm{~km}^{2}$ ) across the Prairie Pothole Region of North and South Dakota, and northeastern Montana. Differences in percent full values reflect the influence of geographic location on wetland percent full. Estimates were derived from models developed from observations of $\sim 50,000$ wetlands annually on 335-380 $3.22 \mathrm{~km} \times 3.22 \mathrm{~km}$ sample blocks distributed across the Prairie Pothole Region of North and South Dakota and northeastern Montana.

(Figure 3) if a single class and size wetland was distributed equally throughout the region but wetland behavior and breeding duck pair response for these wetlands vary as observed by our survey data.

\section{Conservation treatments}

Two general approaches, protection and restoration, have been used for conserving habitat to support breeding waterfowl in the PPR. Regardless of the approach, compensation is required to either purchase land and interests, or retire and restore land for waterfowl conservation. Land values and restoration costs vary both spatially and temporally. We assumed that market forces and other factors may cause costs to vary over time, but that relative cost among geographic areas will remain similar. 


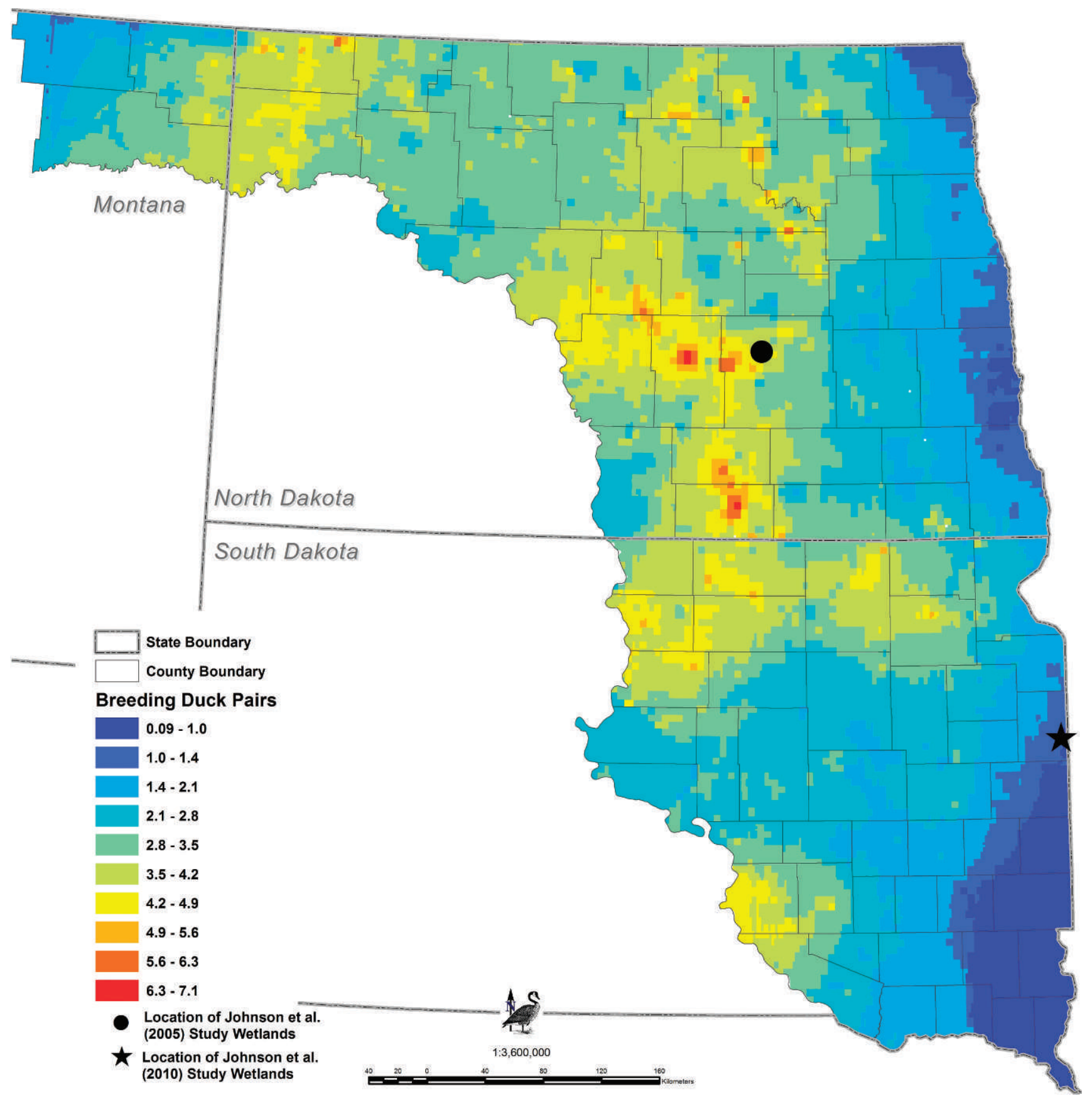

Figure 3. Average estimated density of breeding duck (mallard Anas platyrhynchos, blue-winged teal A. discors, northern pintail $A$. acuta, gadwall A. strepera, and northern shoveler A. clypeata) distribution under a scenario where one 0.89 ha seasonal wetland is distributed uniformly (i.e., 1 wetland / $2.59 \mathrm{~km}^{2}$ ) across the Prairie Pothole Region of North and South Dakota, and northeastern Montana. Differences in pair values reflect the influence of wetland performance and geographic preference of breeding ducks.

Habitat protection in priority conservation areas. Protection of existing wetland and grassland habitats in the U.S. PPR is accomplished either through fee-title acquisition or the purchase of limited-interest easements. Fee-title purchases transfer the ownership of the land to the respective buyer. Future land management and use is controlled by the purchasing agency, organization, or individual. United States Fish and Wildlife Service limitedinterest easements are perpetual, and ownership of the land remains with the easement seller. Fish and Wildlife Service easement agreements prohibit specified alterations to wetland basins (e.g., draining, filling, burning) and grasslands (e.g., conversion to other uses). The easement allows the landowner management and continued use of the land similar to that exercised before the easement purchase. For existing grassland and wetland habitats in priority protection areas defined by the FWS (GAO 2007), we used county assessment 
valuations for 2008 provided by the FWS NWRS Realty Offices in North Dakota, South Dakota, and Montana, and associated adjustments relative to the target habitats (i.e., wetland, grassland) (Table S1, Supplemental Material, http://dx.doi.org/10.3996/032011-JFWM-020.S1). For counties where current FWS Realty valuations were not available, we used USDA county level land values reported in 2008 (http:// www.nass.usda/gov) (Table S5, Supplemental Material, http:// dx.doi.org/10.3996/032011-JFWM-020.S1).

Habitat restoration outside priority conservation areas. When wetland and upland nesting habitats have been converted to other uses (e.g., row-crop agriculture) or degraded in productivity due to some stressor (e.g., climate change), restoration locally or elsewhere is required if the net ecological productivity of the landscape is to be maintained. Restoring habitat is generally more expensive than protecting existing habitat, and is focused toward areas where wetland and grassland resources existed historically but have been converted to other uses, primarily agriculture (USDA 2009). Upland habitats are generally retired from agricultural production and planted to mixes of tame or native grasses and forbs (USDA Farm Service Agency 2011). Wetland restoration usually consists of restoring the hydrology that has been lost through surface drainage, subsurface drainage, or sedimentation (Seabloom and van der Valk 2003). Wetland vegetation is usually left to recover from the existing seed bank, and active planting for most species is seldom required (Wienhold and van der Valk 1989; Galatowitsch and van der Valk 1996). We used USDA easement and restoration costs to model total restoration costs.

For restoration outside of current waterfowl conservation priority areas, we assumed that perpetual conservation was the goal and restoration required both the protection of the land with perpetual limited-interest easements and the added restoration cost for grassland plantings or re-establishment of wetland function. To estimate the costs of providing an additional wetland, by county, we used contract data from the USDA Wetland Reserve Program. Through the Wetland Reserve Program, USDA purchases perpetual wetland easements and restores wetland function and some of the surrounding upland habitat. Consequently, the Wetland Reserve Program data are particularly useful because they represent the actual cost to increase the number and hectares of wetlands, and restoration and protection of surrounding uplands. Each observation in the contract data has both the total cost of the easement and the total restoration cost-the dependent variables in our economic models. Besides easement and restoration costs, the data include the size of the easement and a county identifier. The county identifier allows us to link county data, such as the county-average farmland rental rate, to each observation.

The total cost of an easement is modeled as a function of the total agricultural value of the land and value squared (product and product sq $_{\text {) }}$ and the size of the easement and size squared ( $h a$ and $h a_{s q}$ ). Total agricultural value (product) is calculated by multiplying the county-average/ha rental rate by the number of ha in the easement. Easements payments offset losses landowners face when they sell easements, hence the coefficient on product is positive with decreased marginal effects. The size of the easement plays a role because landowners who sell larger easements may find economic advantages to idle a larger tract of land, irrespective of its productivity, hence the coefficient on ha is negative.

$$
\begin{aligned}
\text { Cost }= & -10600+25.7 * \text { product }-0.000159 * \text { product }_{s q} \\
& -338 * h a-0.121 * h a_{s q}
\end{aligned}
$$

We used a similar specification to model restoration costs. Here, we expect the total costs of restoring wetlands to increase with wetland size, but at a diminishing rate. We expected greater restoration costs on lands with greater soil productivity, given that landowners would be willing to spend more to drain wetlands on more productive lands and assuming that restoration costs are correlated to drainage costs. This model also includes the county-average farm size (farmsize), whether the site is in a rural county (rural ha) where rural $_{\text {ha }}$ equals the number of ha for observations in a rural county and zero otherwise, and a trend variable (trend), which increases by one over time. We expected negative coefficients on farmsize and rural ha because larger farms tend to have large equipment that can be used to lower restoration costs, and rural areas tend to have lower construction costs. We expected real construct/restoration costs to have increased over time, and therefore a positive coefficient on trend.

Because restoration costs were zero for nearly $30 \%$ of our 2,323 observations, we used a Tobit specification (i.e., a combined probability and linear regression model) to estimate probable restoration costs (i.e., Prob[Restore]) (Lee 1993). The Tobit procedure simultaneously estimates the probability that the dependent variable is nonzero and its expected size.

$$
\begin{aligned}
& \operatorname{Prob}(\text { Restore })=-15800+160 * h a+0.0464 * h a_{s q} \\
& +2.82 * \text { product }-0.0000143 * \text { product }_{s q} \\
& -14.3 * \text { rural }_{\text {ha }}-48.3 * \text { farmsize } \\
& +4930 * \text { trend }
\end{aligned}
$$

\section{Results}

\section{Wetland behavior and pair attractiveness}

Wetlands are the key to attracting waterfowl to a particular geographic area (Johnson and Grier 1988). The current distribution of wetlands in the region (Figure 1) is primarily a function of past glacial events and anthropogenic conversion efforts. Approximately 2.6 million wetland basins remain in the region of which $50 \%$ were temporary, $43 \%$ were seasonal, $7 \%$ were semipermanent, and $<1 \%$ were lake (FWS National Wetlands Inventory circa 1984; FWS HAPET, Bismarck, North Dakota, unpublished data). 
Precipitation patterns, basin size, soil characteristics, catchment size, evaporation, drainage activity, and other factors influence the presence and duration of water in individual wetland basins during the breeding season. Although we believe it is virtually impossible for any model to account for all of the factors that influence hydrologic performance, our data from monitoring $\sim 50,000$ wetlands annually since 1987 allowed us to create models that estimate general spatial and temporal wetness patterns across the region (Reynolds et al. 2006). The time series of our data (1987-2008) encompassed a wide range of wetland conditions in the region. Relatively dry conditions existed during years 1987-93, and average to extremely wet conditions occurred from 1994-2008 (Niemuth et al. 2010). Seasonal wetlands were chosen to illustrate the variation in wetland conditions and duck pair attractiveness because of the importance of this basin class to waterfowl. Seasonal wetlands are numerous and support the highest density of breeding pairs (pairs/ha) in the region (Reynolds et al. 2006), and are important brood wetlands when wet (Cox et al. 1998; Krapu et al. 2000). Our data indicate that in general, seasonal wetlands in the far eastern and northwestern portions of the region demonstrated the lowest probability of being full during May and on average tend to be $<50 \%$ of capacity, while wetlands in portions of the Missouri Coteau, Prairie Coteau and north-central Glaciated Plain (Bluemle 1991) exhibit a higher probability of being full of water for breeding waterfowl and often exceed $70 \%$ of capacity (Figure 2).

Our data show that ducks settle on wetlands of the same class and wet area at different densities across the geographic region (Figure 3). Generally, each of the five species occurs in higher density (pairs/ha for each wetland class) in the more westerly portions of the region than in the eastern portion. The factors that influence this pattern are not clear, but we suggest this is due, in part, to a combination of the availability, suitability, and quality of the existing wetland and grassland habitat, and apparent geographic range characteristics of the various species. We found that northern pintail, gadwall, and northern shoveler occurred at very low densities in the eastern areas of the region regardless of wetland availability, whereas mallard and blue-winged teal were distributed more evenly across the geographic region relative to wetland availability (Figures 4-8).

\section{Waterfowl pair distribution}

Contrary to the premise underlying Figure 3, wetlands are not distributed equally across the region. The current wetland distribution (Figure 1) varies greatly by class and size due to natural (Bluemle 1991) and anthropogenic (Dahl 1990) events. Additionally, data from the FSM survey show that different class wetlands attract and support different densities of breeding pairs. The capacity of wetlands in the region to collect and retain surface water and support breeding waterfowl is based on complex interactions between climate, landform, land-use, position in the watershed, geographic location, wetland class, soils, and other factors (Mitsch and
Gosselink 1993; Voldseth et al. 2007). Our survey data were used to model some of these relationships and estimate the breeding duck pair carrying capacity of individual wetlands and wetland complexes. The average abundance and distribution of the five common upland nesting species of breeding waterfowl for the period 1987-2008 in the region is presented in Figure 9 (also see Figures 4-8 for species distribution). Not surprisingly, the distribution of waterfowl demonstrates patterns that are similar to the distribution of wetlands.

Estimated pair densities for individual wetlands are influenced by the basin size, class and location (Reynolds et al. 2006). Temporary and seasonal wetlands are critical to duck production in the region and support nearly $70 \%$ of the breeding pairs. They are small (e.g. $>90 \%$ of the basins are $<0.41 \mathrm{ha}$ ) and productive as a result of nutrient cycling during frequent dry periods (Weller 1987; van der Valk 1989). While $93 \%$ of all wetlands in the region are temporary and seasonal, they only comprise $45 \%$ of the wetland area.

\section{Habitat easement and restoration cost}

Estimates for the cost of habitat restoration included both land protection (i.e., easement) and resource restoration costs. The easement and restoration costs were modeled for each county within the FWS conservation low priority area (i.e., <25 pairs $/ 2.59 \mathrm{~km}$ ). Easement costs were a function of the easement size and county rental rates. The model's ordinary least squares regression coefficients were statistically significant at the 99\% confidence level and had the expected signs. While there may be some correlation between some of the independent variables, the statistical significances of the coefficients (Table 1) suggest that any bias is likely to be small. More importantly, the purpose of these models is to estimate easement costs so the coefficient bias is not a concern. With an adjusted coefficient of variation of 0.81 , the model generates fairly reliable county-level estimates of the costs of limitedinterest wetland easements. Restoration costs were a function of wetland size, soil capability, and farm size. The signs of the coefficients are as expected and each is significant at the $99 \%$ confidence level.

Together, these models provide our county-level estimates of wetland costs. That is, we estimate total wetland costs by generating and summing estimates of Cost and Prob[Restore]. We solved these equations for a 0.89 ha wetland in 2008 by using the county-level values for the other independent variables.

\section{Waterfowl productivity and conservation costs}

The ultimate goal of waterfowl conservation in the PPR is to positively affect population growth through recruitment (PPJV 2005) (i.e., ratio of females added to the population at year $t+1$ to females in the population at year $t$ surviving to $t+1$ ). We used our modeled number of hatchlings as an index of recruitment to spatially assess the relative potential of areas of the region to produce ducklings (Figure 10). Similarities in the distribution of hatchlings and pairs are evident in the western portion of the region, especially along the Missouri 


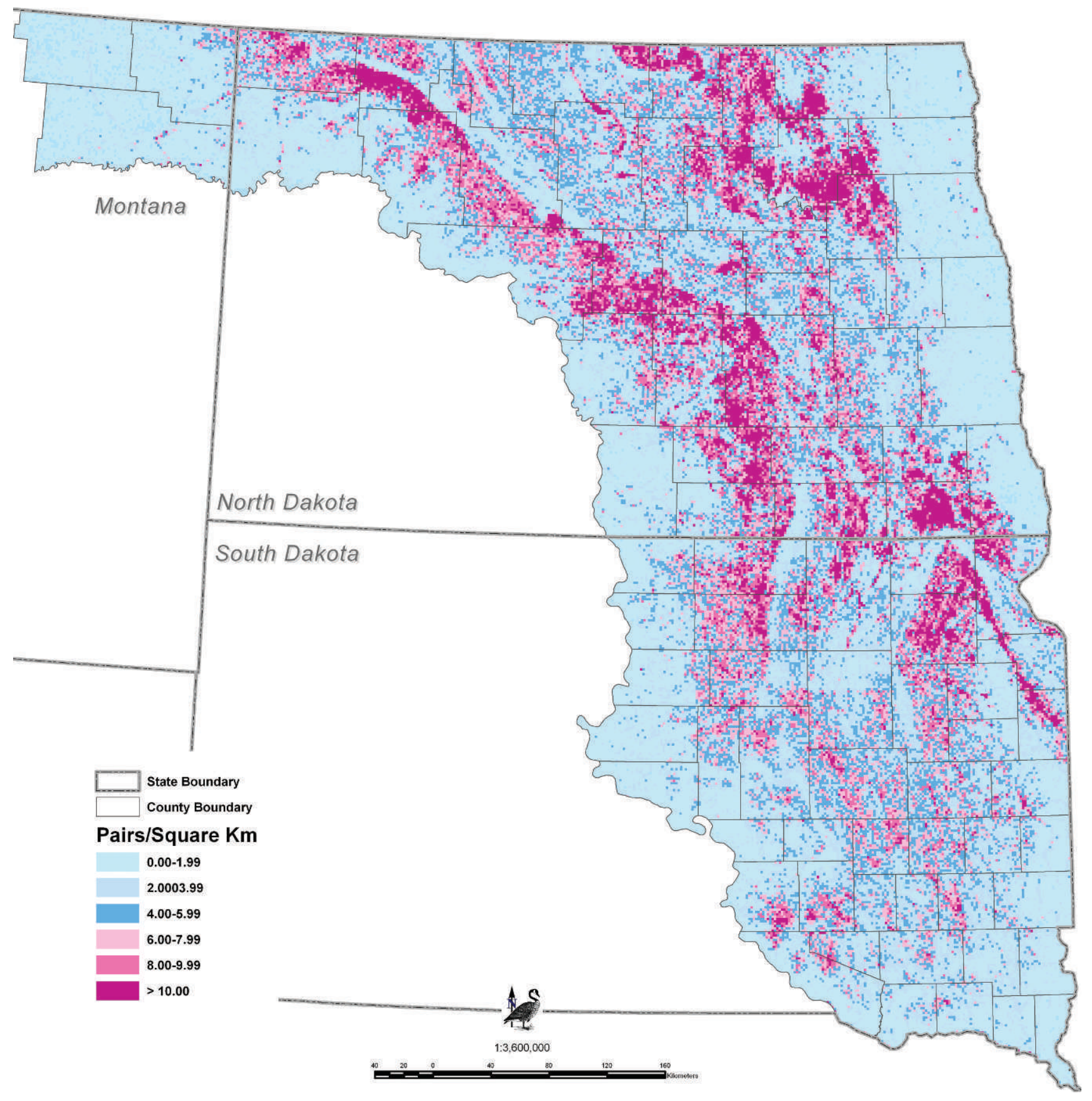

Figure 4. Average estimated mallard Anas platyrhynchos breeding pair distribution in the Prairie Pothole Region of North and South Dakota, and northeastern Montana. Estimates were derived from breeding waterfowl pair surveys conducted during the U.S. Fish and Wildlife Service 4-mi ${ }^{2}$ breeding waterfowl and habitat survey during 1987-2008.

Coteau. This relationship is less evident in the central and eastern portion of the region. The lower numbers of hatchlings in the eastern and northeastern portion of the region, even where high numbers of pairs are predicted, is a function of the relatively lower estimates of nest success associated with lower amounts of grassland nesting cover (Reynolds et al. 2001).

Ratios of hatchlings per unit cost for grassland habitat are presented in Figure 11(A) and for wetland habitat in Figure 11(B). The cost effectiveness of protecting grassland habitat in the highest breeding duck density areas is
$1,067(10.67 / 0.01)$ times greater than the benefit of restoring grasslands in the areas of lowest duck density. For wetlands, the benefit of protecting existing habitat in areas of highest potential duck productivity is about 71 (263.95/3.71) times greater than restoring wetlands in the areas of lowest production potential.

\section{The economic cost of conserving and restoring biological outcomes - an example}

We chose two similar-sized counties in North Dakota to illustrate the economic differences associated with 


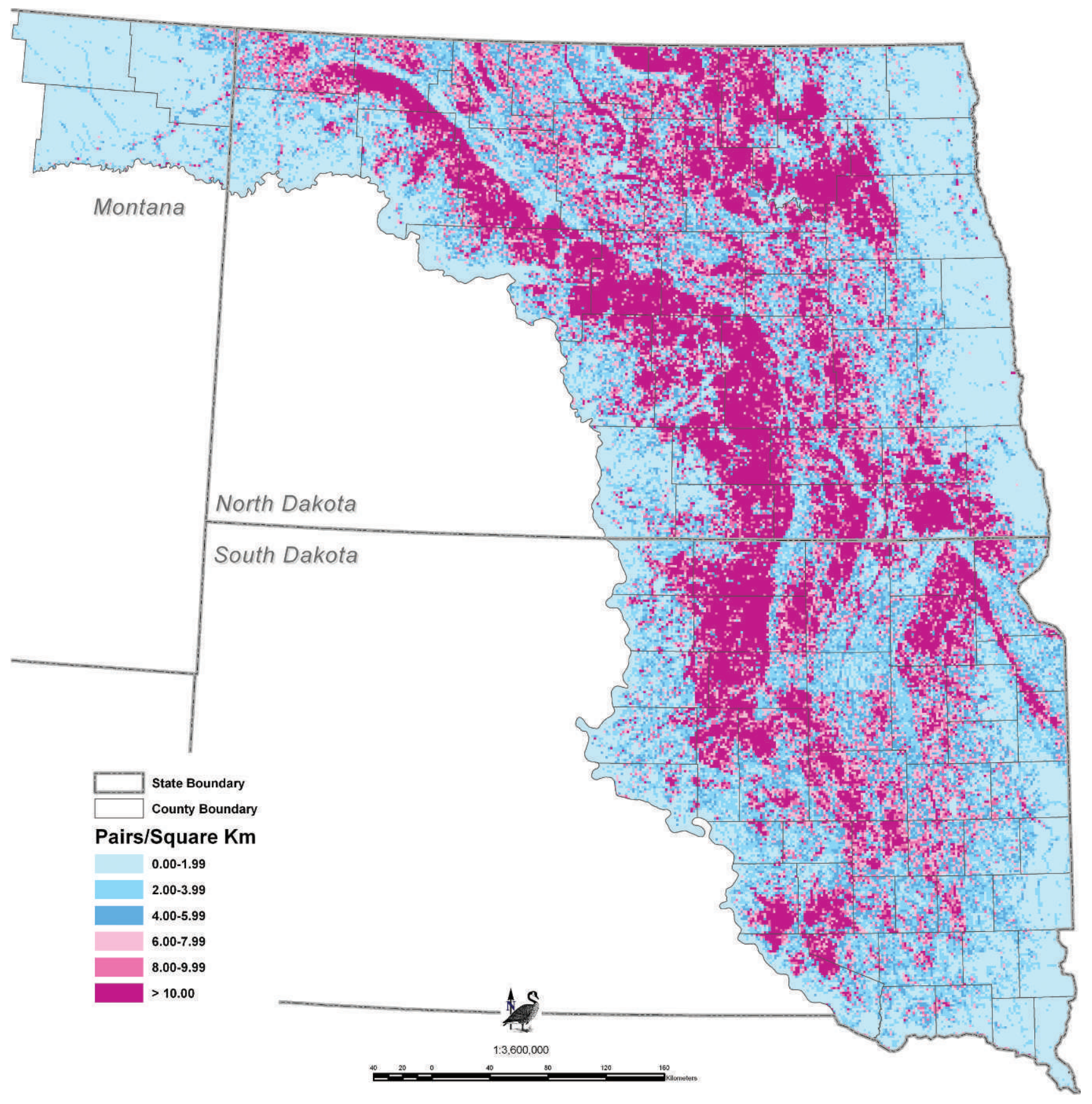

Figure 5. Average estimated blue-winged teal Anas discors breeding pair distribution in the Prairie Pothole Region of North and South Dakota, and northeastern Montana. Estimates were derived from breeding waterfowl pair surveys conducted during the U.S. Fish and Wildlife Service 4-mi ${ }^{2}$ breeding waterfowl and habitat survey during 1987-2008.

conserving comparable biological outcomes across the region (Figure 12). Sheridan County is located in the western portion of the region and has abundant wetland ( $n=43,182$ temporary, seasonal, and semi-permanent basins; $166,036 \mathrm{ha})$ and grassland $\left(1,323 \mathrm{~km}^{2} ; 50.8 \%\right.$ of area) resources. Traill County is located in the eastern portion of the region where extensive wetland drainage and grassland conversion have occurred. Consequently, low wetland ( $n=4,429$ temporary, seasonal, and semipermanent basins; $19,676 \mathrm{ha})$ and grassland $\left(126.9 \mathrm{~km}^{2}\right.$; $5.7 \%$ of the area) resources remain (FWS HAPET,
Bismarck, North Dakota, unpublished data). The size of the two counties are not the same; consequently, wetland and grassland resources and the associated biological outcomes for Sheridan County were scaled downward by $15 \%$ to standardize target biological benefits between counties. We focused on seasonal wetlands to be consistent with the cost analysis for wetland restoration and used values reported above in the conservation treatments section to estimate cost.

Pair Resources. The existing seasonal wetlands in Sheridan County provide habitat for a large number of 


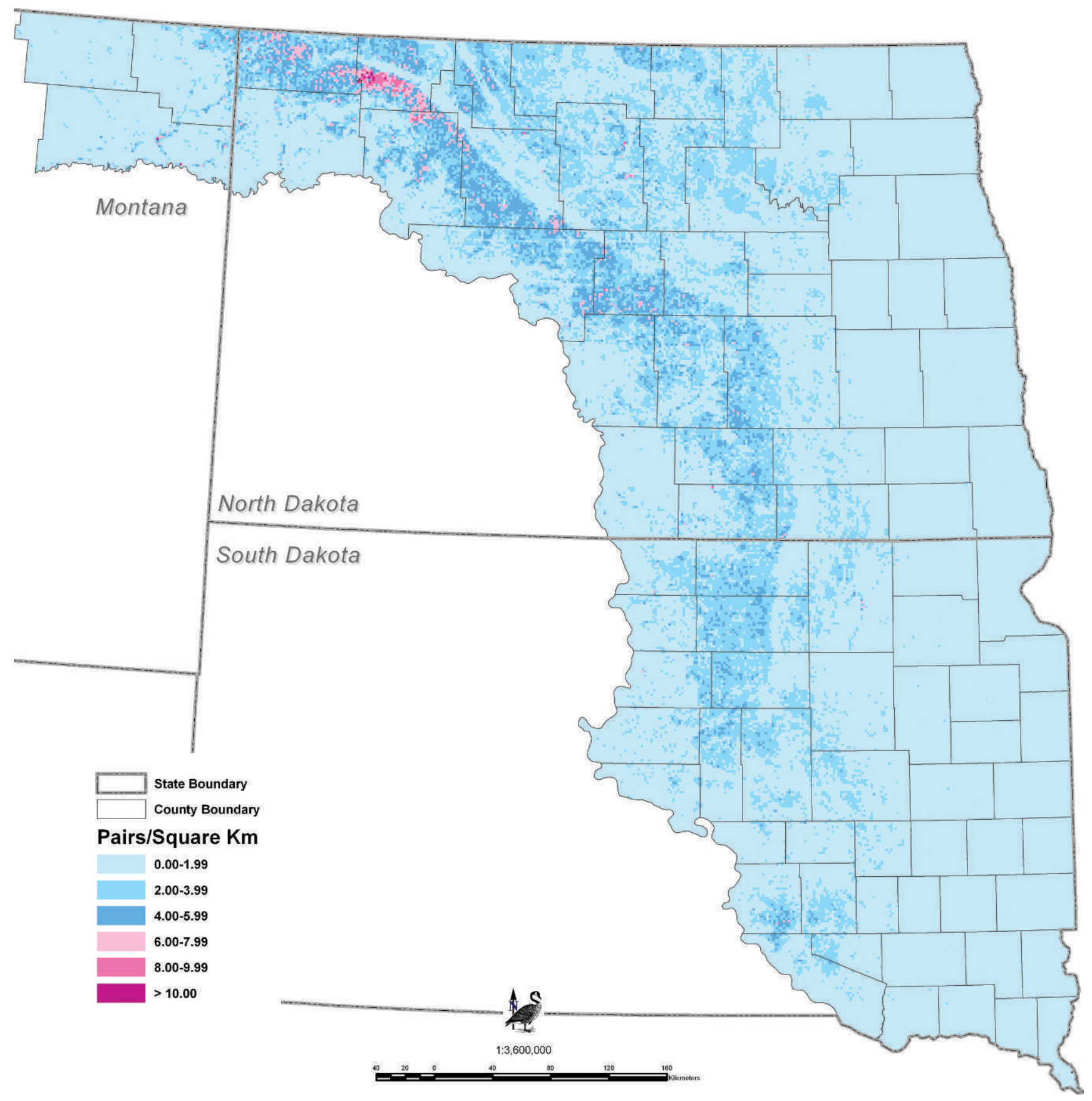

Figure 6. Average estimated northern pintail Anas acuta breeding pair distribution in the Prairie Pothole Region of North and South Dakota, and northeastern Montana. Estimates were derived from breeding waterfowl pair surveys conducted during the U.S. Fish and Wildlife Service 4-mi ${ }^{2}$ breeding waterfowl and habitat survey during 1987-2008.

breeding pairs compared to those remaining in Traill County (Table 2). Both protection and restoration of wetlands are necessary in Traill County to create the wetland resources with equivalent biological benefits for breeding pairs. Breeding pair densities on seasonal wetlands in the western portion of the region are higher than seasonal wetlands in the eastern portion of the region (8.53 vs. 5.14 pairs/ha) (Figure 3). As a result, the wetland resource need exceeds a 1-to-1 replacement of area (i.e., 1.6:1 [Table 2]) to realize the same benefit. From an economic perspective, protecting the existing seasonal wetlands in the western portion of the region is 6.9 times more cost effective than protecting the remaining wetlands and restoring an additional 8,440 ha of seasonal wetlands in the eastern portion of the region to provide equivalent breeding pair benefits (Table 1).

Hatchling Resources. The large number of breeding pairs and the amount of remaining grassland in Sheridan County, have the potential to produce large numbers of hatchlings (Table 2). We used the target breeding population for Traill County (i.e., 44,792 [Table 2]) and the relationship between percent grass, nest success, 


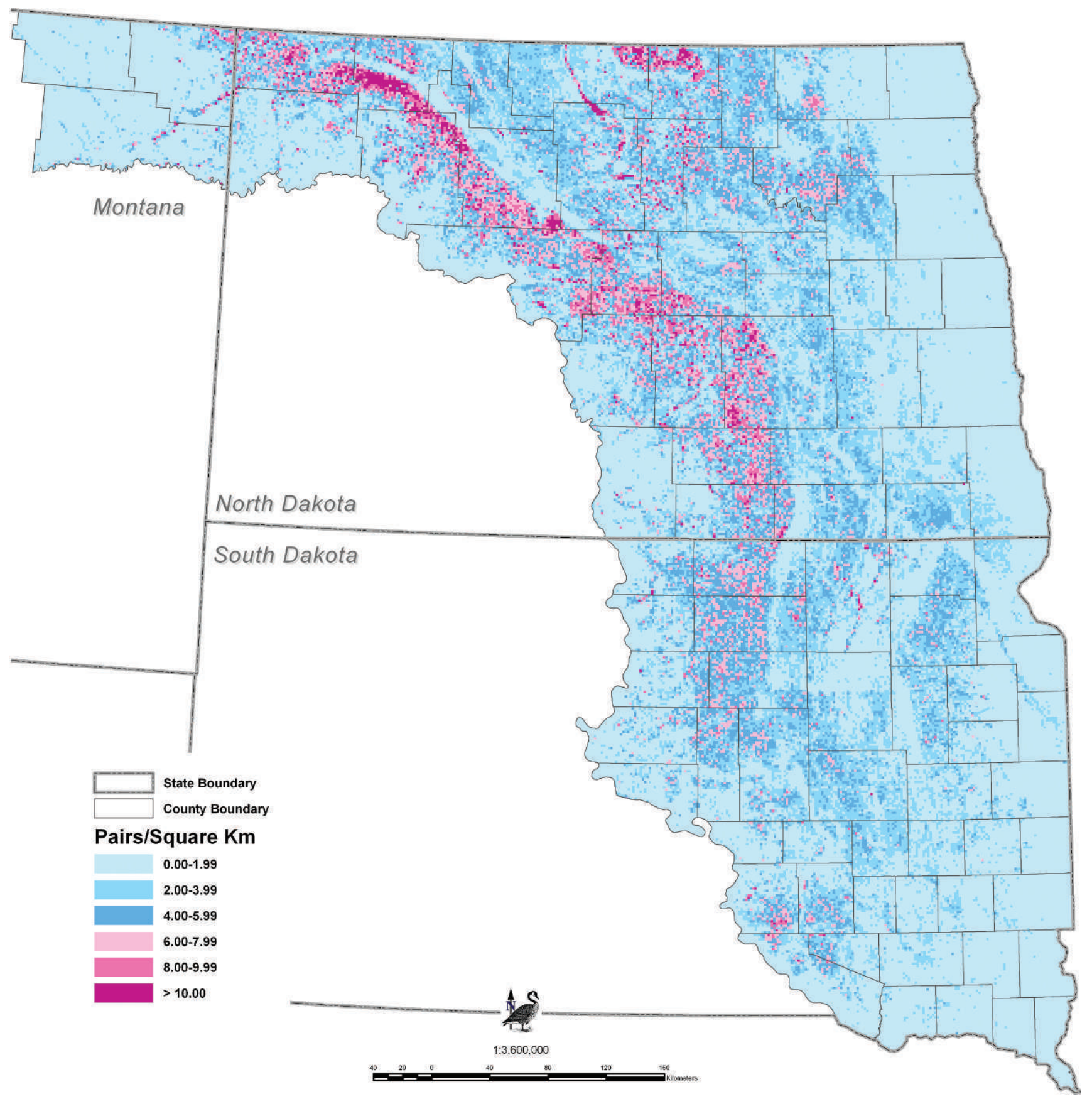

Figure 7. Average estimated gadwall Anas strepera breeding pair distribution in the Prairie Pothole Region of North and South Dakota, and northeastern Montana. Estimates were derived from breeding waterfowl pair surveys conducted during the U.S. Fish and Wildlife Service 4-mi ${ }^{2}$ breeding waterfowl and habitat survey during 1987-2008.

and hatchlings to estimate the amount of grassland needed in Traill County to realize hatchling benefits equivalent to those in Sheridan County. Using this approach suggests that all of the uplands in Traill County need to be protected and the cropland restored to grassland. However, even with this level of protection/ restoration, only $55 \%$ of the biological benefit would be realized (Table 2). Because the attainable biological benefits from protecting and restoring grasslands are not equivalent in this comparison of similar-sized areas, we cannot identify the specific biological benefit:cost ratio. However, in this scenario, it is 9.71 times more cost effective to conserve the existing wetland and grassland resources in Sheridan County (i.e., the western portion of the region) than restore a comparable sized area in the eastern portion of the region, and at the same time potentially realize nearly twice the biological benefit.

\section{Discussion}

Decisions regarding the delivery of conservation programs is driven both by biological and social factors. Evaluating potential habitat management actions as a 


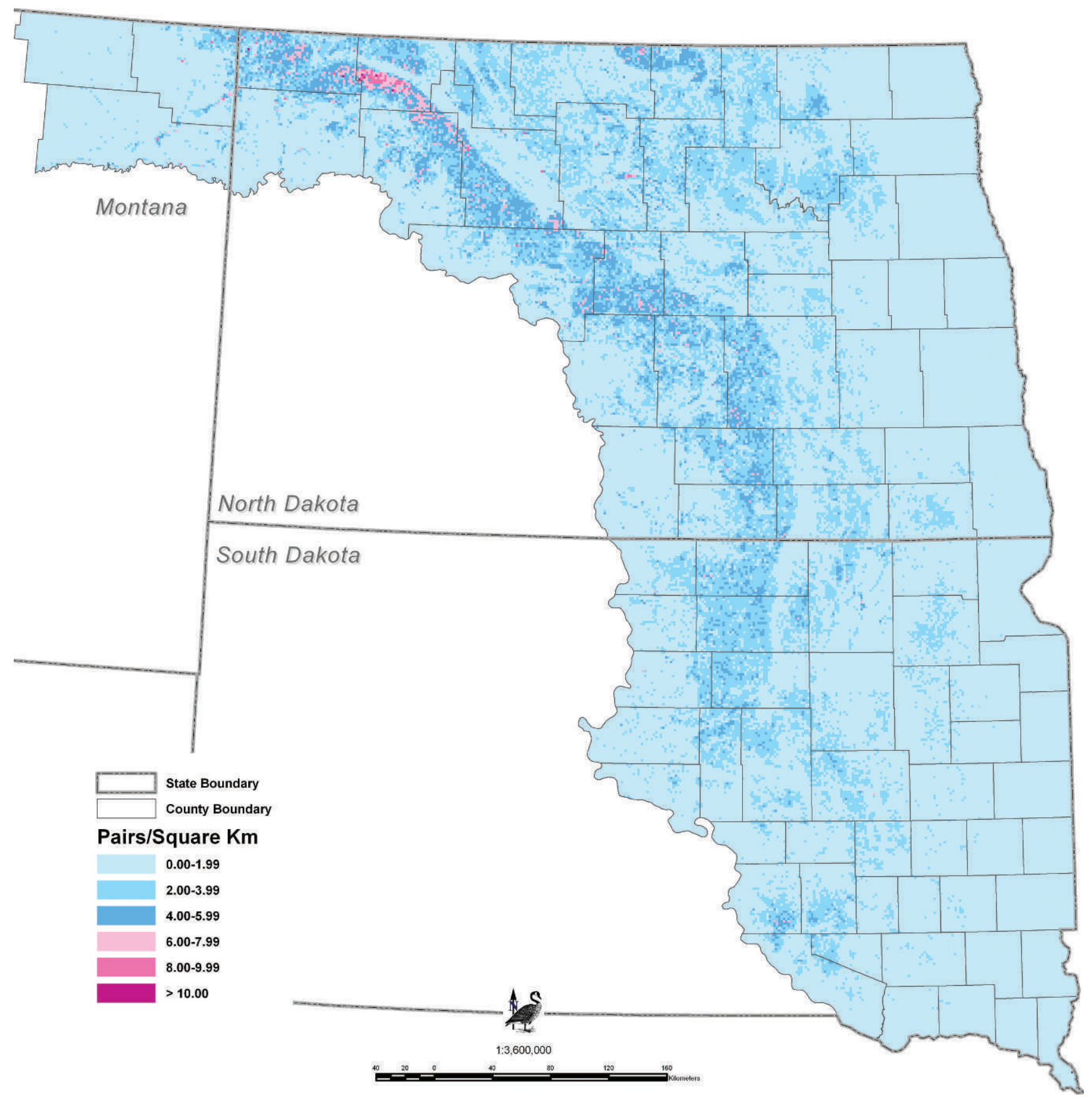

Figure 8. Average estimated northern shoveler Anas clypeata breeding pair distribution in the Prairie Pothole Region of North and South Dakota, and northeastern Montana. Estimates were derived from breeding waterfowl pair surveys conducted during the U.S. Fish and Wildlife Service 4-mi ${ }^{2}$ breeding waterfowl and habitat survey during 1987-2008.

function of climate change predictions necessitates both a biological and economic assessment to evaluate the outcomes of different options. We compared the relative benefit:cost ratio of breeding waterfowl habitat protection in the current conservation focus area where adequate wetland and grassland resources remain versus the cost of protection and restoration further east where most waterfowl habitat has been converted to agricultural uses. Relative cost per hatchling was estimated separately for grassland and wetland easement purchas- es in priority areas where population density is $\geq 25$ pairs $/ 2.59 \mathrm{~km}^{2}$, and grassland and wetland restoration in areas where population density is $<25$ pairs $/ 2.59 \mathrm{~km}^{2}$. These levels of waterfowl population are consistent with the conservation strategy presented in the Prairie Pothole Joint Venture Implementation Plan (PPJV 2005; Joint Ventures are partnerships between federal and state agencies, non-governmental conservation organizations, and private groups and citizens that were established to deliver conservation under the North 


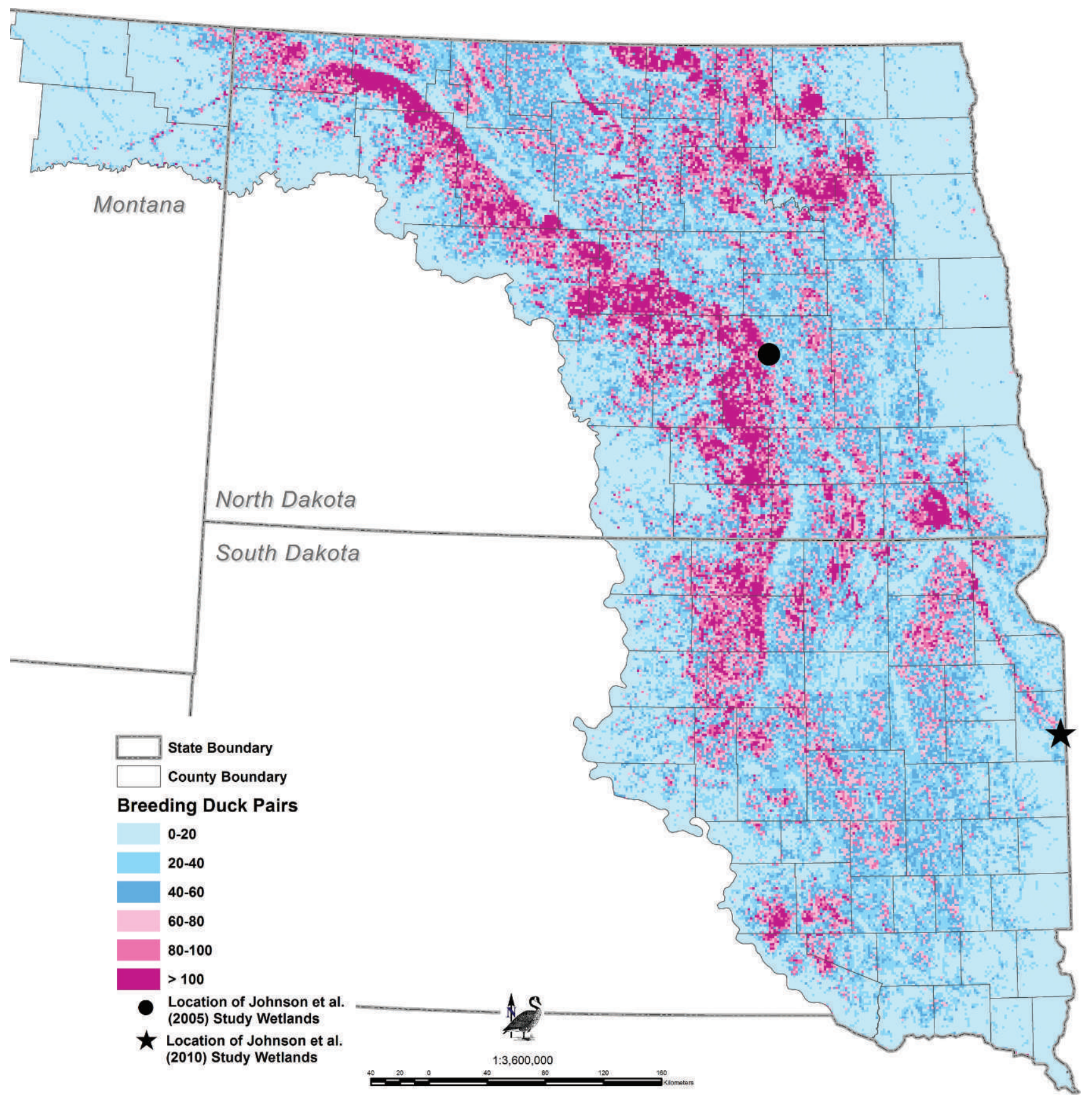

Figure 9. Average estimated breeding pair distribution and density of five combined duck species (mallard Anas platyrhynchos, blue-winged teal $A$. discors, northern pintail A. acuta, gadwall A. strepera, and northern shoveler A. clypeata) in the Prairie Pothole Region of North and South Dakota, and northeastern Montana from surveys conducted from 1987-2008. Estimates were derived from breeding waterfowl pair surveys conducted during the U.S. Fish and Wildlife Service 4-mi ${ }^{2}$ breeding waterfowl and habitat survey during 1987-2008.

American Waterfowl Management Plan [FWS 1986] to help conserve the continent's waterfowl populations and habitats).

Many factors affect the relative costs of protecting or restoring habitats. From a financial perspective, the cost (dollars/ha) for wetland conservation is higher than for grassland conservation, and the benefit:cost is lower in counties in the eastern portion of the North Dakota and
South Dakota PPR. Wetlands are 4-5 times more expensive to restore per hectare than are grasslands (Hansen et al. in prep). Additionally, considerably more restored hectares are required for grasslands when compared to wetlands to realize a measureable biological benefit from each (i.e., hatchlings, breeding pairs) (C. Loesch, FWS HAPET, Bismarck, North Dakota, unpublished data). Regardless of cost and quantity differences, 
Table 1. Variables, coefficients, and standard errors for models used to estimate perpetual easement and restoration costs for wetlands and grasslands in low priority landscapes (i.e., $<25$ pairs $/ 2.59 \mathrm{~km}$ ) for waterfowl habitat conservation in North and South Dakota, and northeast Montana.

\begin{tabular}{llcc}
\hline Model & Parameter & Coefficient & Standard error \\
\hline Perpetual Easement & Intercept & -10600 & -1710 \\
& Product & 25.7 & 0.381 \\
& Product $_{\text {sq }}$ & -0.000159 & 0.00000334 \\
& ha & -338.000 & -18.300 \\
\hline Restoration & ha $_{\text {sq }}$ & -0.121 & -0.00448 \\
& Intercept & $-15,800$ & $-2,720$ \\
& ha & 160 & 17.6 \\
& ha & 0.0464 & 0.004 \\
& Product & 2.82 & 0.321 \\
& Product $_{\text {sq }}$ & -0.0000143 & -0.00000252 \\
& Rural $_{\text {ha }}$ & -98.4 & -11.0 \\
& Farmsize & -48.3 & -3.57 \\
& Trend & 4,930 & 259 \\
\hline
\end{tabular}

both suitable wetland and grassland habitats are essential for maintaining waterfowl populations at current levels. The objective is to use the appropriate, most cost-effective conservation treatment that addresses the landscape deficiencies and limiting factors for waterfowl in a given area. The example above detailing the economic cost of conserving and restoring biological outcomes clearly illustrates the financial, biological, and societal challenges of shifting habitat protection and restoration efforts. Relative to central and western areas, significantly greater resources would need to be expended in the eastern areas to achieve the same waterfowl benefits.

\section{The cost of making a Type I error with regard to climate change}

Type I error is the probability of rejecting the null hypotheses when it is true. If the working hypothesis being tested is: "climate change will shift the geographic distribution of productive waterfowl habitat," then the null hypothesis is "climate change will not shift the geographic distribution of productive waterfowl habitat." In other words, the null hypothesis supports the idea that relative patterns of waterfowl productivity will not change and habitats that are currently the most productive should continue to be the focus of conservation efforts. In this case, a Type I error is made if the null hypothesis (i.e., current habitat conservation targeting is appropriate) is rejected in favor of an incorrect prediction about wetland habitat and subsequent bird response to any changes in climate that might occur.

The recent scenario-based projections of climate change in the PPR by Johnson et al. (2005, 2010), suggest a long-range forecast where climatic conditions that are conducive for supporting wetlands favorable for breeding waterfowl will shift eastward. Ideally, hypotheses would be developed from the scenario-based predictions and validated (or not) using empirical models developed from additional data collected in the future. Unfortunately, long-range forecasts that predict uncertain outcomes (i.e., climate, habitat conditions, breeding waterfowl distributions) may not be testable until it is "too late" to correct a misdirected adaptation strategy developed in response to climate change projections. In the face of uncertainty, decision makers often are encouraged to invoke the "Precautionary Principle," which promotes the position that precautionary actions should be taken even though we cannot know for certain what will happen (see Nudds 1999). However, there is a potential downside to the precautionary approach if substantial harm to the target resource results from changing directions unnecessarily. The PPR currently is experiencing wetland (Oslund et al. 2010; C. Loesch, FWS HAPET, Bismarck, North Dakota, unpublished data) and grassland conversion (Stephens et al. 2009; Rashford et al. 2011) of priority habitats that require immediate attention to maintain current waterfowl and other wildlife populations. Any sizeable redirection of the limited resources currently available for wetland and grassland conservation comes at a considerable cost both in terms of the amount of habitat that can be impacted, and the potential biological outcomes (e.g., duck pairs, hatchlings). This in turn will diminish our ability to maintain current waterfowl populations into the future in the event of a Type I error. We believe this may be the case for waterfowl conservation in the PPR, given the current known risks of habitat conservation relative to the speculative risk of climate change that might occur 50-100 years in the future.

\section{Uncertainty, conservation targeting, and waterfowl production}

Uncertainty is inherent to natural resource management and climate change should be viewed as an additional potential source of environmental variation to be integrated into adaptive management efforts and for consideration in management decisions (Nichols et al. 2011). In the PPR, uncertainty associated with environmental variation is observed primarily as wet-dry cycles that are essential to maintaining wetland productivity (Murkin et al. 2000). Climate change in the PPR and the forecasted sensitivity of wetlands and subsequent impacts on waterfowl populations have been examined recently (Bethke and Nudds 1995; Larson 1995; Sorenson et al. 1998; Anderson and Sorenson 2001; Johnson et al. 2005, 2010; Withey and van Kooten 2011) and suggest that pothole wetlands will be drier and support lower breeding waterfowl populations (e.g., 58\% lower than the long-term average [Sorenson et al. 1998]). Most recently, projections of climate change from Johnson et al. $(2005,2010)$ suggest that western and central portions of the PPR will become drier, and shorter hydroperiods for seasonal and semi-permanent wetlands should be expected. In anticipation of these potential changes, Johnson et al. $(2005,2010)$ recommended that current waterfowl conservation efforts be refocused eastand northward within the PPR. The scientific foundation of the current waterfowl conservation strategy in the region (PPJV 2005; GAO 2007) is a long-term breeding population and habitat survey (i.e., FSM) (Reynolds et al. 


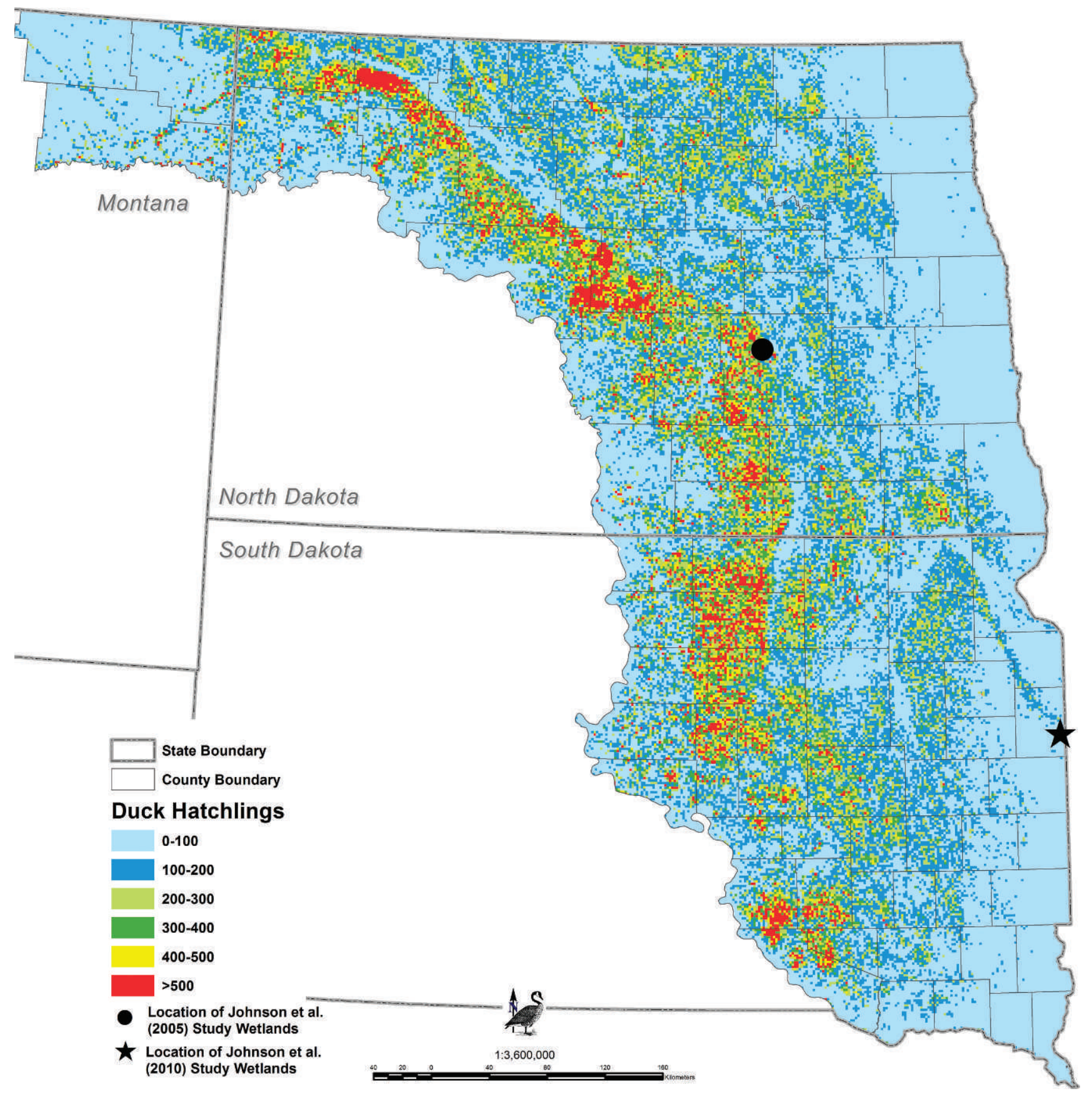

Figure 10. Relative estimated duck hatchlings produced / $2.59 \mathrm{~km}^{2}$ in the Prairie Pothole Region of North and South Dakota, and northeastern Montana. Estimated hatchlings are a function of breeding population, nest success, re-nesting propensity, and clutch size for five species (mallard Anas platyrhynchos, blue-winged teal A. discors, northern pintail A. acuta, gadwall A. strepera, and northern shoveler $A$. clypeata). Nest success is a function of percent grass in a $3.22 \mathrm{~km} \times 3.22 \mathrm{~km}$ land area and geographic location (Reynolds et al. 2001).

2006) and any suggestion to redirect current conservation targeting for waterfowl in the PPR should be seriously considered and investigated prior to adopting the recommendation. Three factors limit the conservation community's ability to make conservation delivery decisions based on the recommendation from Johnson et al. (2005, 2010).

As a measure of historic climate, Johnson et al. (2005, 2010) used weather data from 19 weather stations distributed across the PPR to project their models using global climate change predictions from the Intergovernmental Panel on Climate Change Report (IPCC 2007) to adjust climate input. This approach assumes the only difference between wetlands used to develop their models and other wetlands throughout the PPR is climate. Our analyses of wetland behavior indicate that size, spatial location, and proximity to other wetlands influence basin wetness, as well as potentially other factors (e.g., precipitation, soils, catchment size). 


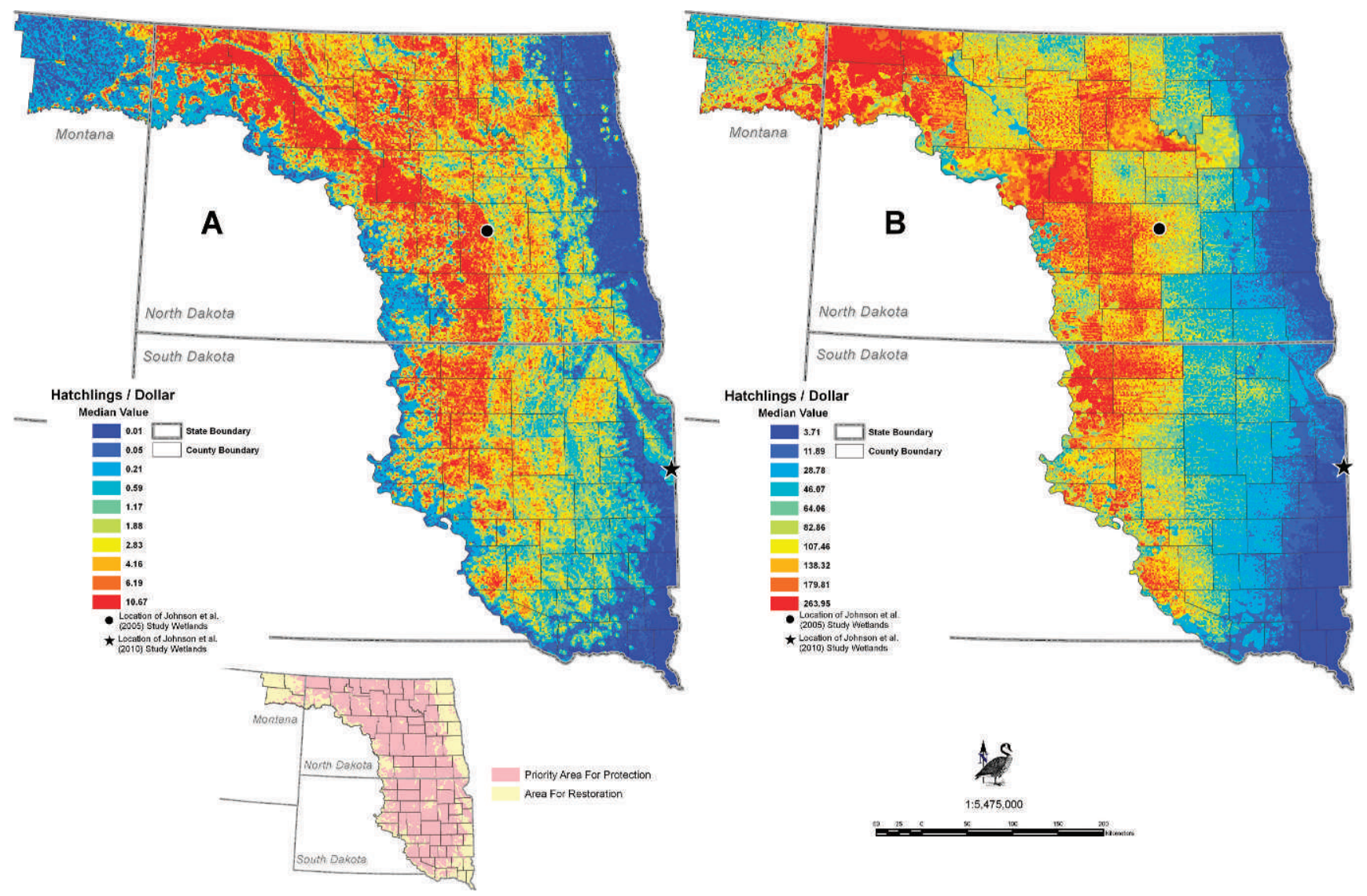

Figure 11. Relative cost of producing duck hatchlings for five species (mallard Anas platyrhynchos, blue-winged teal $A$. discors, northern pintail A. acuta, gadwall A. strepera, and northern shoveler A. clypeata) using grassland (A) or wetland (B) protection in priority areas ( $\geq 25$ breeding pairs / $2.59 \mathrm{sq} \mathrm{km}, 1987-2008$ ) versus the cost of restoring grasslands or wetlands in areas of lower pair density. The model used in this assessment accounts for differences in land value, management input, and hatchling production.

Predictions by Johnson et al. $(2005,2010)$ about changes in wetland hydro-period and distribution due to climate change are based on a small number and limited spatial distribution of reference wetlands (see Figures 16) that may or may not be representative of the wetland population in the PPR. Additionally, wetland response to climate change is assumed to be similar for all wetlands of the same class. Our models of basin wetness (Figure 2) indicate that wetlands are not full at the onset of spring and the distribution of percent full is not homogeneous (Figure 2, Niemuth et al. 2010). This variability should be considered in assessments of climate change that make spatial inferences of wetland response and availability.

Finally, duck population growth is not solely a function of wetland availability. Nesting habitat, nest success, and brood survival are key factors affecting productivity. Creating or restoring a wetland in response to expected changes in precipitation patterns and wetland hydroperiod could result in unintended negative consequences relative to recruitment where breeding duck pairs are attracted to wetlands in agricultural landscapes where nest success is likely to be low (Reynolds et al. 2001). Wetland conservation needs to be a companion to upland conservation and is best accomplished in areas where other landscape elements are sufficiently interspersed and juxtaposed to support adequate nest success and other components for recruitment to waterfowl populations.

In this analysis we did not attempt to predict the impact of future climate changes on waterfowl populations. However, the recent past suggests that basins across the region have become wetter (Niemuth et al. 2010) and attract more breeding duck pairs compared to previous decades. During the 17-year period 1994-2010, the average number of May ponds counted in the eastern U.S. PPR waterfowl survey strata was 2.0 million (range 1.3-2.9 million), an increase of $62 \%$ compared to 1.2 million (range 0.7-1.9 million) during the 20-year period from 1974-1993 (data from FWS 2010a). Longterm trends in breeding duck abundance also show increases since 1994 (Solberg et al. 2008). These increases occurred throughout the survey area during a period when global levels of $\mathrm{CO}_{2}$ and temperature also increased (IPCC 2007). Whether these trends will continue is uncertain. Even if these trends do not continue and climate change results in diminished wetland habitat in the western and central areas of the U.S. PPR, our data suggest the potential decrease in productivity of the present priority areas would have to be dramatic to offset the difference in cost effectiveness between the current conservation strategy verses shifting focus to areas farther east where massive 


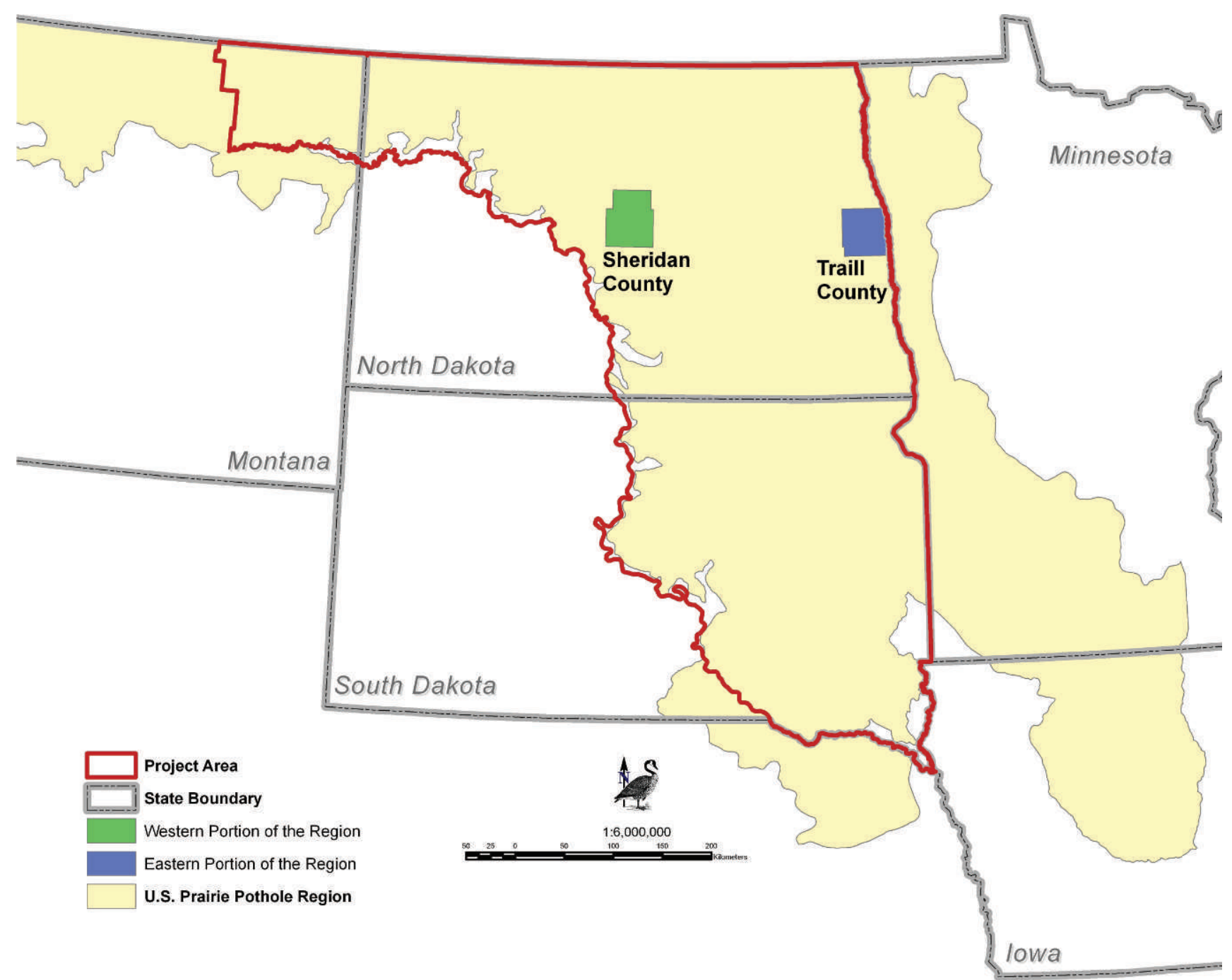

Figure 12. Locations of Sheridan and Traill Counties, North Dakota, USA, and their spatial location relative to the project area and the U.S. Prairie Pothole Region.

restoration of both wetland and upland habitat would be required. Additionally, given the results of the example above for Sheridan and Traill Counties, North Dakota, the restoration necessary to obtain the desired biological outcome may not be attainable. The productivity of the present priority habitats would have to be diminished, or benefits of new conservation increased similarly, by three orders of magnitude for grasslands and nearly two orders of magnitude for wetland habitats (see Figure $11 \mathrm{~A}$ and $11 B)$ to justify shifting emphasis away from easement acquisitions in the western and central portion of the region toward restoration work farther east where both grassland and wetland habitat loss has been severe and land values are relatively high.

\section{Recommendations}

A great amount of uncertainty remains regarding the impact of climate change, particularly at local scales such as the PPR. Projecting global predictions of temperature or precipitation change to local regions such as the PPR does not yield precise insight about the actual and/or observed impact of climate change. The assessment presented here includes data only from North and South Dakota and northeastern Montana. Johnson et al. (2005, 2010) suggest that in the U.S., areas farther east in Minnesota and lowa will have the best climate for wetland habitat to attract and support breeding ducks in the future. To fully address the range of possible geographic shift in suitable waterfowl habitat, the benefit:cost analyses presented here should be applied to these areas also. In FWS Region 6 (i.e., states of Colorado, Kansas, Montana, Nebraska, North Dakota, South Dakota, Utah, Wyoming), the NWRS has made recent adjustments to focus its easement and acquisition programs to include the results of the most recent (i.e., 2008) analysis of data collected during the FSM. Consistent with an adaptive management approach and the considerable uncertainty associated with climate change impacts, continuing to intensively monitor habitat and populations to detect change in habitat and concurrent responses by waterfowl and other migratory birds appears to be a prudent approach (see 
Table 2. Economic comparison of conservation costs necessary to achieve comparable breeding duck pair and hatchling benefits for five species of ducks (i.e., mallard Anas platyrhynchos, blue-winged teal $A$. discors, northern pintail $A$. acuta, gadwall $A$. strepera, and northern shoveler A. clypeata) in two counties in North Dakota. Sheridan County is located in the Missouri Coteau physiographic region in central North Dakota (i.e., western portion of the region) and Traill County is located in the Red River Valley physiographic region in eastern North Dakota (i.e., eastern portion of the region). Conservation actions include protection of existing wetland and grassland resources with conservation easements, and wetland and grassland restoration. Biological measures for Sheridan County were scaled (i.e., $-15 \%$ ) to standardize the area of the two counties.

\begin{tabular}{|c|c|c|c|c|c|c|}
\hline County & $\begin{array}{l}\text { Biological } \\
\text { measure }\end{array}$ & Resource & $\begin{array}{c}\text { Conservation } \\
\text { action }\end{array}$ & ha & Cost/hab & Total cost $\mathrm{t}^{\mathrm{a}}$ \\
\hline \multicolumn{7}{|l|}{ Sheridan } \\
\hline & $44,792^{c}$ & Wetland & Protect existing & 5,254 & 741.00 & $3,893,214.00$ \\
\hline & $328,555^{d}$ & Grassland & Protect existing & 132,251 & 432.25 & $57,165,494.75$ \\
\hline Total cost & & & & & & $61,058,708.75$ \\
\hline \multicolumn{7}{|l|}{ Traill } \\
\hline & $1,396^{\mathrm{C}}$ & Wetland & Protect existing & 272 & $2,324.27$ & $632,201.44$ \\
\hline & $43,396^{c}$ & & Restore/create $\mathrm{e}^{\mathrm{e}}$ & 8,440 & $3,103.95$ & $26,198,394.05$ \\
\hline & $7,359^{d}$ & Grassland & Protect existing & 12,687 & 580.45 & $7,364,343.29$ \\
\hline & $173,318^{d}$ & & Restore & 201,879 & $2,560.65$ & $516,941,106.54$ \\
\hline Total cost & & & & & & $551,136,045.32$ \\
\hline
\end{tabular}

Nichols et al. 2011). Changes in wetland habitats related to climate change are likely to be gradual as opposed to catastrophic. As a result, when long-term changes are detected through continued, intensive monitoring (e.g., FSM), waterfowl conservation partners in the U.S. PPR can utilize current, spatially explicit decision support tools to make adjustments in conservation delivery. This approach is likely to be less risky than reacting to predictions made for 50-100 years into the future. Increased predictive precision could also result from the development of "down-scaled" climate models that focus on the local impacts of climate change. Such models could be set up in a competing process using observed data to identify the model(s) that make the most accurate predictions. This would perhaps create greater confidence in a particular model or model suite on which management decisions would be based. In the meantime, continuing to focus wetland and grassland conservation and protection (e.g., fee-title and easement acquisitions) in the central and western U.S. PPR that currently provide the best benefit:cost ratio with regard to waterfowl production is both a biologically- and costeffective strategy.

\section{Supplemental Material}

Please note: The Journal of Fish and Wildlife Management is not responsible for the content or functionality of any supplemental material. Queries should be directed to the corresponding author for the article.

Table S1. Description of field headings in Table S2, Table S3, and Table S4.

Table S2. Estimates of breeding pair values, hatchlings, and resource restoration biological outcomes and costs.
Breeding pairs estimates were derived from waterfowl surveys conducted during the U.S. Fish and Wildlife Service 4- $\mathrm{mi}^{2}$ breeding waterfowl and habitat survey during 19872008 in North and South Dakota and northeast Montana. Hatchling estimates were derived from a conceptual model utilizing breeding pair abundance and distribution, nesting parameters, and nest success from Reynolds et al. (2001). Restoration biological outcomes are estimates of breeding pair use of restored wetlands and hatchlings resulting from grassland restoration.

Table S3. Biological outcomes and benefit:cost ratios for waterfowl conservation in priority waterfowl conservation areas in North and South Dakota and northeast Montana. Ratios utilize biological outcome estimates for breeding duck pairs and hatchlings, and estimated cost of wetland and grassland conservation (i.e., protection, restoration).

Table S4. Estimated wetland percent full value and location (easting, northing; Universal Transverse Mercator, NAD83, zone 14) for a 0.61 ha seasonal wetland distributed across North and South Dakota and northeast Montana. Estimates are derived from wetness models presented in Reynolds et al. (2006).

Table S5. Land values used to estimate easement costs (US $\$ / h a$ ) of purchasing easements for wetlands in cropland and grasslands in North and South Dakota, and northeast Montana. Sources for 2008 land values were the U.S. Fish and Wildlife Service Realty Offices located in the 3 states and the U.S. Department of Agriculture, National Agricultural Statistics Service (NASS).

All found at DOl: http://dx.doi.org/10.3996/032011JFWM-020.S1 (35 MB XLSX). 


\section{Acknowledgements}

We would like to thank Brian Wangler, FWS Region 6 HAPET FSM Survey Biologist for his dedication and diligence to coordinate and manage all aspects of the FSM survey from 1996-2010. We would also like to thank the hundreds of FWS NWRS staff in North Dakota, South Dakota, and northeast Montana for their annual commitment to conduct field breeding waterfowl surveys for the past 24 years. Helpful comments on earlier drafts were provided by Kevin Willis, Neal Niemuth, Seth Mott, and Will Meeks, and we appreciate the critical review and constructive comments by the Subject Editor and reviewers, Jim Dubovsky and Dave Olson.

The views expressed are those of the authors and not necessarily those of the USFWS, the USDA, or the Economic Research Service.

The use of trade, firm, or product names is for descriptive purposes only and does not imply endorsement by the U.S. Government.

\section{References}

Anderson MG, Sorenson LG. 2001. Global climate change and waterfowl: Adaptation in the face of uncertainty. Transactions of the North American Wildlife and Natural Resources Conference 66:200-319.

Batt BDJ, Anderson MG, Anderson CD, Caswell FD. 1989. The use of prairie potholes by North American ducks. Pages 204-227 in van der Valk A, editor. Northern prairie wetlands. lowa State University Press, Ames.

Bellrose FC. 1980. Ducks, geese, and swans of North America. Stackpole Books, Harrisburg, Pennsylvania.

Bethke RW, Nudds TD. 1995. Effects of climate change and land use on duck abundance in the prairieparklands. Ecological Applications 5:588-600. Available: http://www.jstor.org/pss/1941969.

Bluemle JP. 2000. The face of North Dakota, third edition. Educational series 26, North Dakota Geological Survey, Bismarck.

Cox RR, Hanson MA, Roy CC, Euliss NH, Johnson DH, Butler MG. 1998. Mallard duckling growth and survival in relation to aquatic invertebrates. Journal of Wildlife Management 62:124-133. Available: http://www.jstor. org/pss/3802270.

Cowardin LM, Carter V, Golet FC, LaRoe ET. 1979. Classification of wetlands and deepwater habitats of the United States. U.S. Fish and Wildlife Service, Office of Biological Science-79/31. Available: http://library. fws.gov/FWS-OBS/79_31.pdf.

Cowardin LM, Shaffer TL, Arnold PM. 1995. Evaluations of duck habitat and estimation of duck population sizes with a remote-sensing system. Biological Science Report 2, National Biological Service, Washington, D.C. Available: http://www.npwrc.usgs.gov/resource/birds/ duckhab/index.htm.

Dahl TE. 1990. Wetlands losses in the United States 1780's to 1980's. U.S. Department of the Interior, Fish and Wildlife Service, Washington, D.C. Available: http://www. npwrc.usgs.gov/resource/wetlands/wetloss/index.htm.
[GAO] Government Accounting Office. 2007. Prairie Pothole Region: at the current pace of acquisitions, the U.S. Fish and Wildlife Service is unlikely to achieve its habitat protection goals for migratory birds. Report to the Subcommittee on Interior, Environment, and Related Agencies, Committee on Appropriations, House of Representatives. United States Government Accountability Office. 07-1093. Available: http://www. gao.gov/new.items/d071093.pdf.

Galatowitsch SM, van der Valk AG. 1996. Characteristics of recently restored wetlands in the Prairie Pothole Region. Wetlands 16:75-83.

Hansen L, Loesch CR, Reynolds RR. In prep. Cost-effective funding of waterfowl habitat restoration in the Prairie Pothole Region: a spatial analysis.

Hoekman ST, Mills LS, Howerter DL, Devries JH, Ball IJ. 2002. Sensitivity analyses of the life cycle of midcontinent mallards. Journal of Wildlife Management 66:883900. Available: http://www.jstor.org/pss/3803153.

[IPCC] Intergovernmental Panel on Climate Change. 2007. Climate change 2007: synthesis report. Abdelkader A, Bojariu R, Diaz S, Elgizouli I, Griggs D, Hawkins D, Hohmeyer O, Jallow BP, Kajfez-Bogata L, Leary N, Lee H, Wratt D, editors. IPCC Plenary XXVII. Available: http:// www.mendeley.com/research/symposium-report-timeto-adapt-climate-change-and-the-european-waterdimension-vulnerbility-impacts-adaptation-berlin-12-to14-february-2007/.

Johnson DH, Grier JW. 1988. Determinants of breeding distributions of ducks. Journal of Wildlife Management Wildlife Monograph 100. Available: http://www.jstor. org/pss/3830704.

Johnson RR, Higgins K. 1997. Wetland resources in eastern South Dakota. South Dakota State University, Brookings.

Johnson WC, Millett BV, Gilmanov T, Voldseth RA, Guntenspergen GR, Naugle DE. 2005. Vulnerability of northern prairie wetlands to climate change. Bioscience 55:863-872.

Johnson WC, Werner B, Guntenspergen GR, Voldseth RA, Millett B, Naugle DE, Tulbure M, Carroll RWH, Tracy J, Olawsky C. 2010. Prairie wetland complexes as landscape functional units in a changing climate. BioScience 60:128-140.

Krapu GL, Pietz PJ, Brandt DA, Cox RR. 2000. Factors limiting mallard brood survival in prairie pothole landscapes. Journal of Wildlife Management 63:553561. Available: http://www.jstor.org/pss/3803253.

Larson D. 1995. Effects of climate on numbers of northern prairie wetlands. Climatic Change 30:169-180.

Lee L. 1993. Multivariate tobit models in econometrics. Pages 145-173 in Maddala GS, Rao CR, Vinod HD, editors. Handbook of Statistics, vol. 11. Amsterdam: North-Holland.

Mitsch WJ, Gosselink JG. 1993. Wetlands. Second edition. Van Nostrand Reinhold, New York.

Murkin HR, van der Valk AG, Clark WR. 2000. Prairie wetland ecology: the contribution of the Marsh Ecology Research Program. lowa State University Press, Ames. 
Nichols JD, Koneff MK, Heglund PJ, Knutson MG, Seamans ME, Lyons JE, Morton JM, Jones MT, Boomer GS, Williams BK. 2011. Climate change, uncertainty, and natural resource management. Journal of Wildlife Management 75:6-18.

Niemuth ND, Reynolds RE, Granfors DA, Johnson RR, Wangler B, Estey ME. 2008. Landscape-level planning for conservation of wetland birds in the U.S. Prairie Pothole Region. Pages 533-560 in Millspaugh JJ, Thompson FR, editors. Models for planning wildlife conservation in large landscapes. Elsevier Science.

Niemuth ND, Wangler B, Reynolds RE. 2010. Spatial and temporal variation in wet area of wetlands in the Prairie Pothole Region of North Dakota and South Dakota. Wetlands 30:1053-1064.

Nudds TD. 1999. Adaptive management and the conservation of biodiversity. Pages 179-291 in Baydack RK, Campa H III, Hauflar JB, editors. Practical approaches to the conservation of biological diversity. Island Press, Washington D.C. Available: http://books.google.com/books?hl= en\&lr $=$ \&id = J6plvmUOemAC\&oi $=$ fnd \&pg $=$ PA 179\&dq = Adaptive+management+and+the+conservation+of+ biodiversity\&ots = XvudfUQSau\&sig = Dokloor1Cq RCUGtVBeWPHkFZDU\# $\mathbf{v}=$ onepage $\& \mathrm{q}=$ Adaptive $\%$ 20management\%20and\%20the\%20conservation\%20of $\%$ 20biodiversity\&f $=$ false.

Oslund FT, Johnson RR, Hertel DR. 2010. Assessing wetland changes in the Prairie Pothole Region of Minnesota from 1980 to 2007. Journal of Fish and Wildlife Management 1(2):131-135; e1944-687X. doi: 10.3996/122009-JFWM-027

[PPJV] Prairie Pothole Joint Venture Implementation Plan. 2005. Section I - Plan Foundation. Casey D, Forman KJ, Granfors DA, Johnson RR, Lively CA, Naugle DE, Niemuth ND, Reynolds RR, Ringelman JK. Ringelman JK, editor. Available: http://www.ppjv.org/PPJV_presn tations/2005_PPJV/1_Upfront_matter_Contents.pdf.

Rashford BS, Walker JA, Bastian CT. 2011. Economics of grassland conversion to cropland in the Prairie Pothole Region. Conservation Biology 25:274-284.

Reynolds RE, Cohan DR, Johnson MA. 1996. Using landscape information approaches to increase duck recruitment in the Prairie Pothole Region. Transactions of the North American Wildlife and Natural Resources Conference 61:86-93.

Reynolds RE, Shaffer TL, Renner RW, Newton WE, Batt BDJ. 2001. Impact of the Conservation Reserve Program on duck recruitment in the U.S. Prairie Pothole Region. Journal of Wildlife Management 65: 765-780. Available: http://www.jstor.org/pss/3803027.

Reynolds RE, Shaffer TL, Loesch CR, Cox RR. 2006. The farm bill and duck production in the Prairie Pothole Region: increasing the benefits. Wildlife Society Bulletin 34:963-974.

Seabloom EW, van der Valk AG. 2003. Plant diversity, composition, and invasion of restored and natural prairie pothole wetlands: implications for restoration. Wetlands 23:1-12.
Solberg JW, Liddick TS, Garrettson P, Kruse K, Bentley R, Yparraguirre D, Fleming K, Hoskins J. 2008. Waterfowl breeding population and habitat survey for South and North Dakota. U.S. Fish and Wildlife Service, Division of Migratory Bird Management-BMBS, Bismarck, North Dakota. Available: http://www.fws.gov/migratory birds/NewReportsPublications/WPS/Reports08/Dakotas. pdf.

Sorenson LG, Goldberg R, Root RL, Anderson MG. 1998. Potential effects of global warming on waterfowl populations breeding in the Northern Great Plains. Climatic Change 40:343-369.

Stephens SE, Rotella JJ, Lindberg MS, Taper ML, Ringelman JK. 2005. Duck nest survival in the Missouri Coteau of North Dakota: Landscape effects at multiple spatial scales. Ecological Applications 15: 2137-2149.

Stephens SE, Walker JA, Blunck DR, Jayaraman A, Naugle DE, Ringelman JK, Smith AJ. 2009. Predicting risk of habitat conversion in native temperate grasslands. Conservation Biology 10:1523-1739. Available: http:// www.ppjv.org/PPJV_presntations/Predicting\%20Risk\% 20Habitat\%20Conversion.pdf.

[USDA] U.S. Department of Agriculture. 2009. Summary report: 2007 national resources inventory. U.S. Department of Agriculture, Natural Resources Conservation Service, lowa State University, Ames. Available: http://www.nrcs. usda.gov/Internet/FSE_DOCUMENTS//stelprdb1041379. pdf.

[USDA] U.S. Department of Agriculture Farm Service Agency. 2011. Conservation reserve program monthly summary - January 2011. Available: http://www.fsa. usda.gov/Internet/FSA_File/jan2011crpstat.pdf.

[FWS] U.S. Fish and Wildlife Service. 1986. The North American Waterfowl Management Plan - a strategy for cooperation. U.S. Fish and Wildlife Service, Washington, D.C. Available: http://www.fws.gov/birdhabitat/NAWMP/ files/NAWMP.pdf.

[FWS] U.S. Fish and Wildlife Service. 2010a. Waterfowl population status, 2010. U.S. Department of the Interior, Washington, D.C. Available: http://www.fws.gov/migra torybirds/NewReportsPublications/PopulationStatus/ Waterfowl/StatusReport2010_Final.pdf.

[FWS] U.S. Fish and Wildlife Service. 2010b. 2010 annual report, Migratory Bird Conservation Commission. U.S. Department of the Interior, Washington, D.C. Available: http://www.fws.gov/refuges/realty/pdf/MBCC_2010.pdf.

[FWS] U.S. Fish and Wildlife Service. 2011. Annual report of lands under the control of the U.S. Fish and Wildlife Service. Department of the Interior, U.S. Fish and Wildlife Service Division of Realty, Washington D.C. Available: http://www.fws.gov/refuges/realty/archives/pdf/2010_ Annual_Report_of_Lands.pdf.

van der Valk AG, editor. 1989. Northern prairie wetlands. lowa State University Press, Ames.

Voldseth RA, Johnson WC, Gilmanov T, Guntenspergen GR, Millett BV. 2007. Model estimation of land-use effects on water levels on northern prairie wetlands. 
Ecological Applications 17:527-540. Available: ftp:// ftpext.usgs.gov/pub/er/md/laurel/GCC/Chapter\%203\% 20Lit\%20Cited/Voldseth_2007.pdf.

Weller MW. 1987. Freshwater marshes, ecology and wildlife management. Second edition, University of Minnesota Press, Minneapolis.
Wienhold CE, van der Valk AG. 1989. The impact of duration of drainage on the seed banks of northern prairie wetlands. Canadian Journal of Botany 67:1878-1884.

Withey P, van Kooten GC. 2011. The effect of climate change on optimal wetlands and waterfowl management in western Canada. Ecological Economics 70:798-805. 